\title{
Effect of species diversity on particle clearance and productivity in farmed bivalves
}

\author{
Michael P. Acquafredda*, Daphne Munroe
}

Haskin Shellfish Research Laboratory, Rutgers University, Port Norris, New Jersey 08349, USA

\begin{abstract}
Most bivalve farms are designed as monocultures, yet diverse communities often outperform monocultures in various metrics of ecosystem functioning, including particle clearance and productivity. This study tested the feasibility of bivalve polyculture by examining particle clearance, growth, and survival of 4 species that are economically important to the northeastern USA. Three particle depletion experiments were conducted to determine if more diverse bivalve assemblages had greater clearance rates than those which were less diverse. Different assemblages of Crassostrea virginica, Spisula solidissima, Mercenaria mercenaria, and Mya arenaria were supplied with a single cultured algal species, a mix of 2 cultured algal species, or natural seston. To determine how species richness affects bivalve productivity, growth and survival were monitored in a flow-through mesocosm experiment, which simulated farm conditions. In the cultured algae experiments, more diverse assemblages did not exhibit significantly greater clearance rates than those that were less diverse. Instead, the clearance rates of each species were additive across assemblages. Surprisingly, most assemblages did not display a significant preference for the larger microalgae species, Pavlova lutheri (4.0-6.0 $\mu \mathrm{m})$, over Nannochloropsis oculata $(1.90-3.75 \mu \mathrm{m})$. Most notably, when supplied with natural seston, the 4 -species polyculture demonstrated a significantly greater tank-level clearance rate for particles $<25 \mu \mathrm{m}$ compared to most monocultures. However, nearly all productivity metrics were not significantly affected by species richness. This work suggests that some degree of complementarity exists among these bivalves, and that in non-food limited systems, these bivalves could be co-cultured without outcompeting one another.
\end{abstract}

KEY WORDS: Particle clearance - Bivalve • Aquaculture - Polyculture - Biodiversity · Ecosystem functioning $\cdot$ Niche complementarity $\cdot$ Partitioning

\section{INTRODUCTION}

Farming bivalve mollusks is of high economic importance, as it contributes nearly $11.8 \%$ (US $\$ 19$ billion) to the global first-sale value of cultivated aquatic animals (FAO 2016). In the USA alone, more than 21000 metric tons of farm-raised clam, oyster, and mussel meat were harvested in 2016, valued at over US \$340 million (NMFS 2018). Typically, bivalve farms are designed as monocultures, which can be considered artificial ecosystems dominated by relatively high densities of a single species. While monocultures increase efficiency, they can also be vulnerable to a variety of risks (Altieri et al. 2015).

\footnotetext{
${ }^{*}$ Corresponding author: michael.acquafredda@rutgers.edu
}

Cultivating a diverse suite of species insulates farmers from any individual crop failure, whether it occurs from disease (Felton et al. 2016), predation (Russell 1989), or fluctuating environmental conditions (Gaudin et al. 2015). In this way, polyculture can sustain the economic viability of farm operations, and can even increase profitability by allowing farmers to more easily navigate market forces if the price of each individual crop fluctuates (Chopin et al. 2012, Isaacs et al. 2016). Although most of the evidence outlining the deficiencies of monoculture and the risk-mitigating advantages of polyculture originate from terrestrial agricultural research, these principles are possibly applicable to aquaculture.

() The authors 2020. Open Access under Creative Commons by Attribution Licence. Use, distribution and reproduction are unrestricted. Authors and original publication must be credited. 
Aquatic polyculture, or multispecies aquaculture, is the farming of 2 or more aquatic species that share space or resources. Multi-trophic aquaculture, where organisms of different trophic levels are cultivated in close proximity to one another, has received attention for its ability to reduce the environmental impacts of the fed species. Incorporating unfed species like seaweed and mussels, which extract excess nutrients and particulates from the system, helped mitigate the waste produced by a salmon farm (Chopin et al. 2012). Multispecies aquaculture can also occur on a single trophic level and still confer various advantages compared to single-species culture. For example, different bivalve species bioaccumulate toxins at different rates and store those toxins in varying organs throughout their bodies (Bricelj \& Shumway 1998). Having an alternate crop when one crop becomes too contaminated for sale would benefit a bivalve farmer. Likewise, the growth rates of different species vary by season (Stecher et al. 1996), meaning that different crops can be grown from seed to harvest on different schedules. When farmers grow multiple bivalve species that reach market size during different seasons, they ensure a sustained harvest throughout the year.

Exploitative interspecific competition for food resources among bivalves is a mechanism by which the productivity of a diversified farm may be constrained. However, diverse communities often outperform monocultures for various metrics of ecosystem functioning, including resistance to invasion and community-level resilience (Steiner et al. 2005, 2006), ecosystem stability (Tilman et al. 2006), particle clearance (Whalen \& Stachowicz 2017, Valentine \& Butler 2019), and productivity, i.e. biomass growth (Tilman et al. 2001, Spooner \& Vaughn 2009, Duffy et al. 2016, Liang et al. 2016). There is evidence of positive relationships between diversity and ecosystem functioning in suspension feeders generally, and in bivalves specifically. For example, more species-rich communities of suspension-feeding bryozoans and tunicates demonstrated greater phytoplankton clearance rates, regardless of flow conditions (Whalen \& Stachowicz 2017). Similarly, Spooner \& Vaughn (2009) observed that freshwater mussel biomass increased with species richness across 21 communities.

One of the main mechanisms hypothesized to explain the positive relationship often observed between diversity and ecosystem functioning is niche complementarity (Fox 2005, Tilman et al. 2006, Fargione et al. 2007). Species that perform similar ecosystem functions are often assigned to a collective functional group or guild. Since evolution shapes populations towards more efficient resource use (Duffy et al. 2016), the functional niches of a given species within a guild do not always neatly overlap, resulting in niche complementarity (Rosenfeld 2002). Species within the bivalve suspension-feeding guild compete for suspended particles, but variations in particle selection adaptations that partition the available food resources among taxa would minimize interspecific competition (Lesser et al. 1992, Riera et al. 2002, Novais et al. 2016).

Nearly complete niche overlap likely occurs for the filtration of particles greater than $6 \mu \mathrm{m}$, since most bivalves can retain particles larger than this with $100 \%$ efficiency (Riisgård 1988, Rosa et al. 2018). For smaller particles, $<6 \mu \mathrm{m}$, niche complementary may occur among bivalves because interspecific variation in the morphology of feeding structures causes differences in interspecific capture efficiencies (Riisgård 1988). Likewise, physiochemical interactions between seston and the mucus that lubricates bivalves' feeding apparatus can facilitate differential particle capture (Ward et al. 1994, Beninger et al. 1997, Pales Espinosa \& Allam 2013, 2018). If each species specializes in or prefers filtering a specific set of particles, then more particles overall would be filtered in polycultures than monocultures. However, if species are capable of filtering all particles with equal efficiency, then they would be directly competing for this suspended material.

To date, little work has investigated the viability of bivalve polyculture. Four bivalve species native to the northeastern USA were selected for this study, including eastern oyster Crassostrea virginica, Atlantic surfclam Spisula solidissima, hard clam Mercenaria mercenaria, and softshell clam Mya arenaria. These species are of high economic importance to the region, and their familiarity to farmers makes them the most likely candidates for diversified bivalve farms. C. virginica and M. mercenaria are the 2 most commonly cultured bivalves in the northeastern USA, and their culture techniques are well-studied. Clam gardening and other small-scale aquaculture of $M$. arenaria have historically taken place in locations such as Massachusetts and Maine, but further research into the culture techniques for $M$. arenaria are in active development due to the high demand of this species and the declining wild fishery (Beal et al. 2016, Hagan \& Wilkerson 2018). Commercial-scale S. solidissima aquaculture remains in its infancy, but it has the potential to become an attractive alternate crop for farmers interested in diversifying their farms due to its rapid growth and culture techniques compatible with existing infrastructure (Acquafredda et al. 2019). 

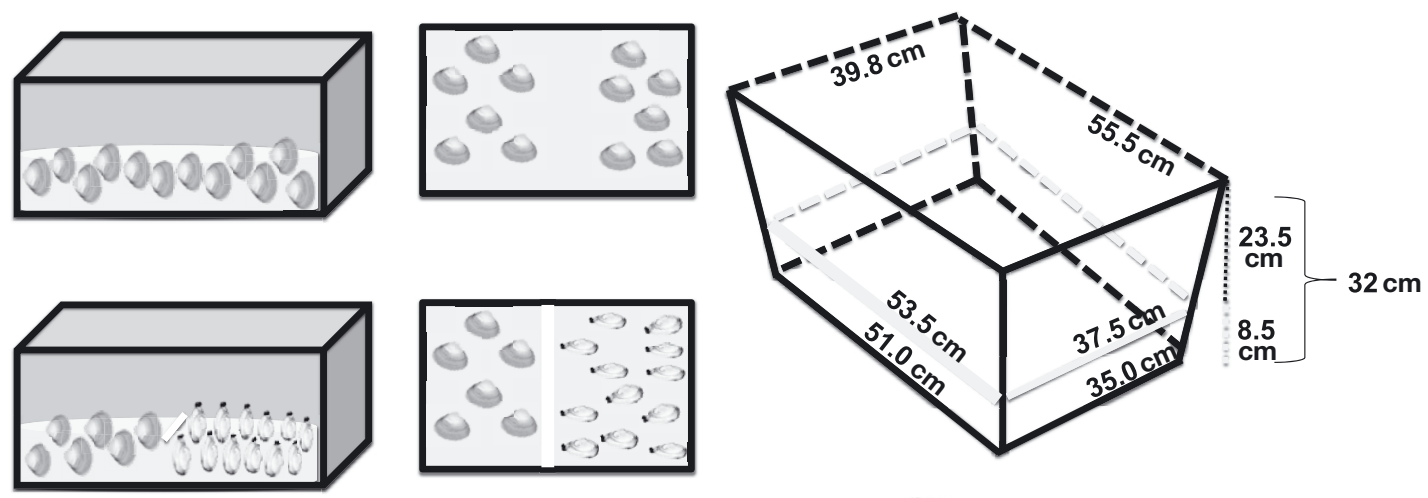

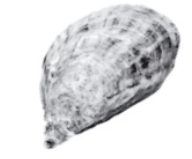

Eastern oyster

C. virginica

(Cv)

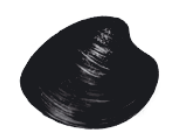

Hard clam

M. mercenaria

(Mm)

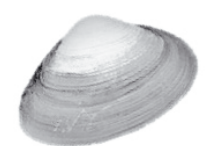

Atlantic surfclam S. solidissima

(Ss)

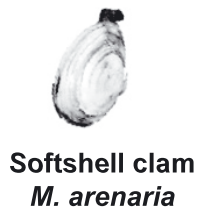

(Ma)

Fig. 1. Mesocosm assembly, showing how (from top to bottom) a monoculture, biculture, triculture, and 4-species polyculture would be assembled in these experiments. Oysters are represented in mesh bags in the tanks. The left and center panels depict the side and top views of the mesocosms, respectively. The right panel shows the bivalves used in this study, as well as the dimensions of each mesocosm. Black and gray lines outline the volume of the container and sediment layer, respectively

In this study, 3 particle depletion experiments were conducted to determine if more diverse bivalve assemblages had greater particle clearance capacity than those which were less diverse. In a series of experiments, different assemblages were supplied with a single cultured algal species, a mix of cultured algal species that differed significantly in size, or unfiltered seawater containing a diverse assemblage of natural seston. Additionally, we investigated whether bivalves grown in diverse assemblages were more productive than those grown in less diverse groups. To assess how species richness affected bivalve productivity, we conducted a fully replicated, fully combinatorial, long-term, flow-through mesocosm experiment that closely matched farm conditions and tracked bivalve growth and survival through time.

\section{MATERIALS AND METHODS}

All experiments were conducted at the Rutgers University New Jersey Aquaculture Innovation Cen- ter (AIC) in North Cape May, NJ. The bivalve seed (6-18 mo old) used in the experiments represent cultured strains and sizes that are commonly used by growers during the initial outplanting of new seed on their farms. Eastern oysters Crassostrea virginica and surfclams Spisula solidissima were produced at the AIC, hard clams Mercenaria mercenaria were procured from a hatchery in Atlantic City, NJ, and softshell clams Mya arenaria were obtained from a hatchery in Beals, Maine.

In all experiments, mesocosms were constructed out of $62 \mathrm{l}$ plastic tanks, each filled with approximately $8.5 \mathrm{~cm}$ of cleaned sand and $41 \mathrm{l}$ of seawater (Fig. 1). Corrugated plastic partitions were buried in the sediment and used to segregate the species (Fig. 1). The bivalves were placed into the mesocosms prior to the start of the experiments, so that the clams had adequate time to bury. Oysters were split between 2 or 4 mesh bags and hung above the sediment. In the particle depletion experiments, an airstone was added to each mesocosm approximately $4 \mathrm{~cm}$ below the surface to gently aerate the tank and to keep the water well mixed. 


\subsection{General particle depletion experimental set-up}

Clearance rate is defined as the volume of water cleared of suspended particles per unit of time, and only equals filtration rate when $100 \%$ of suspended particles are efficiently retained (Møhlenberg \& Riisgård 1979, Riisgård 2001). Previous research on bivalve filtration has determined allometric equations that relate a bivalve's size to its clearance rate. Here, we estimated the expected tank-level clearance capacity of a given mesocosm as the summed clearance rates of all individuals predicted by allometric equations, using the following formula:

$$
\begin{aligned}
& \text { Expected tank }- \text { level clearance rate }= \\
& \qquad \sum_{i=1}^{j} a_{i} \times w_{i}^{b_{i}} \times N_{i}
\end{aligned}
$$

Here, $a$ and $b$ are species-specific constants derived from published allometric equations (Table 1), $W$ is the mean dry tissue weight of a species at the onset of an experiment, $N$ is the number of individuals of each species in the assemblage, and $j$ is the number of species in the assemblage. To determine $W$ for each species, the soft tissue of 5 individuals were placed in a $68^{\circ} \mathrm{C}$ drying oven for $48 \mathrm{~h}$, cooled, and weighed.

The actual particle clearance rate for a given assemblage was measured using the clearance method, which consists of taking water samples over a fixed time interval and measuring the particle concentrations that monotonically decline through time (Riisgård 2001). The observed tank-level clearance rate for a given mesocosm was calculated using the following equation (Coughlan 1969, Riisgård 2001):

Observed tank - level clearance rate $=$

$$
\frac{V}{t} \times \ln \left(\frac{C_{0}}{C_{t}}\right)
$$

where $V$ is the known volume of the mesocosm, $t$ is the time in hours, and $C_{0}$ and $C_{t}$ represent the initial $(t=0)$ and final $(t=5)$ particle concentrations of the mesocosm, respectively. The temperature and salinity of the mesocosms were maintained between 19.0 and $20.5^{\circ} \mathrm{C}$ and between 31.7 and $32.4 \mathrm{ppt}$. Each mesocosm was stocked such that the expected community clearance capacity was approximately $22 \mathrm{l} \mathrm{h}^{-1}$ (Table 2). The focal bivalves used in the particle clearance experiments had mean shell lengths and dry tissue weights that ranged from 18-24 $\mathrm{mm}$ and $0.009-0.073 \mathrm{~g}$, respectively (Table S1). Before each experiment, the animals were starved for $48 \mathrm{~h}$. Experiments were performed between September and October 2017.

\subsection{Cultured algae depletion experiments}

In order to compare clearance rates among bivalve assemblages that differ in species richness when such assemblages have limited food choice availability, mesocosms containing various combinations of bivalves were supplied with a single algal species,

Table 1. Species-specific constants that relate a bivalve's dry tissue weight $(W, g)$ to its clearance rate $\left(C R, \mathrm{l} \mathrm{h}^{-1}\right)$ and are used in allometric equations that take the form $C R=a W^{b}$. These values were selected or adapted from the listed sources, which experimentally derived allometric clearance equations in controlled laboratory-based studies

\begin{tabular}{|lccl|}
\hline Species & $a$ & $b$ & Source \\
\hline $\begin{array}{l}\text { Crassostrea virginica } \\
\text { Spisula solidissima }\end{array}$ & $\begin{array}{l}6.79 \\
4.015\end{array}$ & 0.73 & $\begin{array}{l}\text { Riisgård (1988) } \\
\text { Adapted from Riisgård (1988) } \\
\text { and Riisgård (2001) }\end{array}$ \\
$\begin{array}{lccl}\text { Mercenaria mercenaria } \\
\text { Mya arenaria }\end{array}$ & 2.45 & 0.79 & $\begin{array}{c}\text { Adapted from Riisgård (1988) } \\
\text { and Coughlan \& Ansell (1964) } \\
\text { Riisgård \& Seerup (2003) }\end{array}$ \\
\hline
\end{tabular}

Table 2. Stocking densities and the estimated initial tank-level clearance ca-

\begin{tabular}{|c|c|c|c|c|}
\hline Assemblage & $\begin{array}{c}\text { Crassostrea } \\
\text { virginica } \\
(\mathrm{Cv})\end{array}$ & $\begin{array}{c}\text { Spisula } \\
\text { solidissima } \\
(S s)\end{array}$ & $\begin{array}{c}\text { Mercenaria } \\
\text { mercenaria } \\
(\mathrm{Mm})\end{array}$ & $\begin{array}{c}\text { Мya } \\
\text { arenaria } \\
(\text { Мa })\end{array}$ \\
\hline$C V$ & 104 & & & \\
\hline SS & & 40 & & \\
\hline$M m$ & & & 108 & \\
\hline Ma & & & & 56 \\
\hline$C V+S S$ & 52 & 20 & & \\
\hline$C V+M m$ & 52 & & 54 & \\
\hline$C v+M a$ & 52 & & & 28 \\
\hline$S s+M m$ & & 20 & 54 & \\
\hline$S s+M a$ & & 20 & & 28 \\
\hline$M m+M a$ & & & 54 & 28 \\
\hline$C v+S s+M m$ & 35 & 13 & 36 & \\
\hline$C v+S s+M a$ & 35 & 13 & & 19 \\
\hline$C v+M m+M a$ & 35 & & 36 & 19 \\
\hline$S s+M m+M a$ & & 13 & 36 & 19 \\
\hline$C v+S s+M m+M a$ & 26 & 10 & 27 & 14 \\
\hline
\end{tabular}
pacities used in the particle depletion experiments. In all assemblages, the tank-level clearance capacity was $221 \mathrm{~h}^{-1}$ 
Pavlova lutheri (Strain: Mono), or with 2 species that differed significantly in size, $P$. lutheri and Nannochloropsis oculata. All combinations of the 4 species were compared (Table 2). The single-species and the 2-species algal depletion experiments were each replicated 3 times; each mesocosm contained the same individuals on each occasion. Control mesocosms containing no animals were used to estimate the rate at which the algal cells fell out of the water column. The experiment was conducted in a windowless laboratory under ambient artificial light.

For the single-species algal depletion experiment, live $P$. lutheri were added to each mesocosm at a concentration of $(2.6 \pm 0.4) \times 10^{4} \mathrm{cells} \mathrm{m}^{-1}$. For the 2species algal depletion experiment, live $P$. lutheri and $N$. oculata were added to each mesocosm at a concentration of $(1.3 \pm 0.6) \times 10^{4}$ cells ml ${ }^{-1}$ and $(1.23$ $\pm 0.26) \times 10^{5}$ cells ml $^{-1}$, respectively. Although the concentrations of each algal species differed, the 2 species were similarly abundant in terms of the overall biomass (Helm \& Bourne 2004). The organic dry weight of algal cells used for both depletion experiments ranged from $0.56-0.61 \mathrm{ug} \mathrm{ml}^{-1}$. A beaker was used to collect $50 \mathrm{ml}$ water samples from each mesocosm immediately after the algae were added and once again after $5 \mathrm{~h}$.

The particle concentration of each sample was analyzed with a Beckman Coulter Counter, a particle analyzer that can detect individual particles between 1 and $50 \mu \mathrm{m}$ with high confidence. Each sample was passed through a Melitta ${ }^{\mathrm{TM}}$ coffee filter to remove impurities that might damage the Coulter Counter. Ten $\mathrm{ml}$ of each sample were placed into a cuvette and diluted with $10 \mathrm{ml}$ of $0.1 \mu \mathrm{m}$ filtered seawater, then gently inverted to thoroughly mix the contents. To reduce sampling bias, all samples were run in triplicate, then averaged across the 3 runs. The concentration of $P$. lutheri present in each sample was calculated from the number of particles detected between the sizes of 4.00 and $6.00 \mu \mathrm{m}$. The concentration of $N$. oculata present in each sample was calculated from the number of particles detected between the sizes of 1.90 and $3.75 \mu \mathrm{m}$.

\subsection{Natural seston depletion experiment}

To compare clearance rates among bivalve assemblages that differ in species richness when supplied with natural seston, mesocosms containing various combinations of bivalves were supplied with unfiltered seawater from the Cape May Canal. For this experiment, only the 4 -species polyculture and the 4 monocultures were compared (Tables 2 \& S1).
Three replicate mesocosms were established for each combination. Three control mesocosms containing no animals were also used to estimate the rate at which particles fell out of the water column. The mesocosms had an initial concentration of $(3.1 \pm 0.2) \times 10^{5}$ particles $\mathrm{ml}^{-1}$.

On the day of the experiment, the seawater in each mesocosm was replaced with unfiltered seawater from the Cape May Canal. Care was taken during the water changes to not disturb the sediment nor the buried bivalves. A beaker was used to collect $50 \mathrm{ml}$ water samples from each mesocosm immediately after the tanks were filled and once again after $5 \mathrm{~h}$. Each sample was immediately preserved with $1 \mathrm{ml}$ of $2.5 \%$ Lugol's iodine solution and wrapped in aluminum foil to reduce photodegradation of the preservative.

The particle concentration of each sample was analyzed with FlowCAM, an imaging particle analyzer, which can detect individual particles between 2 and $300 \mu \mathrm{m}$ with high confidence. Each sample was passed over stacked 212 and $38 \mu \mathrm{m}$ sieves (diagonals $=299 \mu \mathrm{m}$ and $54 \mu \mathrm{m}$, respectively), to divide the samples into large and small size classes. All particles retained on the $212 \mu \mathrm{m}$ screen $(>299 \mu \mathrm{m})$ were discarded. Before being analyzed on FlowCAM, all samples were gently inverted to thoroughly mix their contents. To reduce sampling bias, all samples were run in triplicate, then averaged across the 3 runs. Particles retained on the $38 \mu \mathrm{m}$ screen were washed into $20 \mathrm{ml}$ of treated seawater. A $0.95 \mathrm{ml}$ subsample of this size fraction was analyzed on a FC300-FV FlowCell with a $4 \times$ objective lens. Because these samples were concentrated prior to analysis on FlowCAM, the particle concentration data collected were multiplied by 0.4 in order to reflect the concentration of the original samples. Approximately $0.04 \mathrm{ml}$ of the sample fraction passing through the $38 \mu \mathrm{m}$ screen was analyzed on a FC80-7FV FlowCell with a 10x objective. All particle images were sorted into size classes using their estimated spherical diameter.

\subsection{Productivity experimental set-up}

A fully replicated, fully combinatorial, long-term, flow-through mesocosm experiment was conducted to address the hypothesis that more diverse assemblages of bivalves will have greater productivity than those which are less diverse. Here, we define productivity as an increase in the rate at which biomass is assimilated into the individuals of the population. Productivity was calculated as the increase in average daily growth rate of the shell dimensions and 
average daily growth rate of an individual's whole wet weight. Whole wet weight is defined as the weight of the whole living organism with its shells and tissue patted dry; this metric captures changes in both the shell and tissue weights and is reflective of measures used by some aquaculturists to quantify the productivity of their farms (USDA 2014).

The experiment ran for $93 \mathrm{~d}$, from 11 July to 12 October 2017, and each of 3 replicates consisted of 15 mesocosms, containing 1 of each of the potential combinations of $C$. virginica, S. solidissima, M. mercenaria, and $M$. arenaria. Each tank was supplied with unfiltered water from the Cape May Canal at a flow rate of $3.5 \pm 0.16 \mathrm{l} \mathrm{min}^{-1}$ into each mesocosm. A settling tank was used to reduce heavy sediment loads in incoming water. Inflow into each mesocosm was positioned approximately $8 \mathrm{~cm}$ below the surface and water supply was evenly distributed across the entire mesocosm. Water exited each mesocosm via displaced overflow. All mesocosms and associated plumbing were cleared of fouling organisms daily, to ensure that only the focal species contributed to the clearance capacity of each mesocosm.

Bivalves were placed into the mesocosms as previously stated prior to the start of the experiments; all clams were given adequate time to bury themselves, and oysters were placed in bags hanging above the sediment (Fig. 1). Temperature was continuously recorded every $600 \mathrm{~s}$ over the course of the experiment with Seabird Scientific SBE 56 data loggers (Fig. S1 in the Supplement at www.int-res.com/articles/suppl/ m639p107_supp.pdf). Salinity was continuously logged at 15 min intervals using a YSI 6600 V2-4 multi-parameter water quality sonde; data from a nearby NOAA buoy (Station CMAN - 8536110) were used to fill a gap in the dataset (Fig. S2). All mesocosms were initially stocked at a tank-level clearance capacity of $621 \mathrm{~h}^{-1}$, with the exception of those containing $M$. mercenaria, which ranged from $10 \mathrm{l} \mathrm{h}^{-1}$ in the $M$. mercenaria monocultures to $49 \mathrm{l} \mathrm{h}^{-1}$ in the 4 species polycultures (Table 3 ). The focal bivalves used in the productivity experiment had initial mean shell lengths and dry tissue weights that ranged from $17-28 \mathrm{~mm}$ and $0.045-0.088 \mathrm{~g}$, respectively (Table S2).

Once monthly (Day 0, 34, 65, 93), 10 individuals of each species from each species assemblage from each replicate were randomly sampled and the following data were collected: shell length, shell height, shell width, and whole wet weight. Shell length represents the length of the anterior-posterior axis on the clams and the dorsal-ventral axis on the oysters. Shell height represents the dorsal-ventral axis on the clams and the anterior-posterior axis of the oysters. Shell width represents the dextral-sinistral axis of all bivalves. Shell dimension data were collected with calipers (Mitutoyo Absolute ${ }^{\mathrm{TM}}$ Digimatic). Wet weight was measured with a digital scale (Ohaus $\left.{ }^{\circledR}\right)$. All live animals were returned to the same mesocosm after each data collection event. Average daily growth rate was calculated using the following equation (Munroe 2016):

$$
X_{\mathrm{GR}}=\frac{X_{t}-X_{t_{0}}}{\Delta t}
$$

where $X$ represents the average value of a particular growth variable (shell length, shell height, shell width, or whole wet weight), collected on the first and last day of the experiment, and $\Delta t$ represents the number of days of the experiment (=93). Survival was determined by collecting and counting all live and dead individuals within each mesocosm.

\subsection{Statistical analyses}

All data were analyzed with R (v. 3.4.2) using RStudio (v. 1.1383). Normality and homoscedasticity were confirmed using Shapiro-Wilk and Levene's tests, re-

Table 3. Stocking densities and the estimated initial tank-level clearance capacities used in the productivity experiment

\begin{tabular}{|c|c|c|c|c|c|}
\hline Assemblage & $\begin{array}{l}\text { Crassostrea } \\
\text { virginica } \\
\qquad(\mathrm{CV})\end{array}$ & $\begin{array}{c}\text { Spisula } \\
\text { solidissima } \\
(S S)\end{array}$ & $\begin{array}{c}\text { Mercenaria } \\
\text { mercenaria } \\
(\mathrm{Mm})\end{array}$ & $\begin{array}{c}\text { Mya } \\
\text { arenaria } \\
(\text { Ma) }\end{array}$ & $\begin{array}{c}\text { Tank-level } \\
\text { clearance } \\
\text { capacity }\left(\mathrm{l} \mathrm{h}^{-1}\right)\end{array}$ \\
\hline $\mathrm{CV}_{\mathrm{V}}$ & 60 & & & & 63 \\
\hline Ss & & 96 & & & 61 \\
\hline$M m$ & & & 40 & & 10 \\
\hline Ma & & & & 116 & 61 \\
\hline$C V+S S$ & 30 & 48 & & & 62 \\
\hline $\mathrm{CV}+\mathrm{Mm}$ & 30 & & 20 & & 36 \\
\hline $\mathrm{CV}+\mathrm{Ma}$ & 30 & & & 58 & 62 \\
\hline$S s+M m$ & & 48 & 20 & & 35 \\
\hline$S s+M a$ & & 48 & & 58 & 61 \\
\hline$M m+M a$ & & & 20 & 58 & 36 \\
\hline$C V+S S+M m$ & 20 & 32 & 13 & & 44 \\
\hline$C v+S s+M a$ & 20 & 32 & & 39 & 62 \\
\hline$C v+M m+M a$ & 20 & & 13 & 39 & 45 \\
\hline$S s+M m+M a$ & & 32 & 13 & 39 & 44 \\
\hline$C v+S s+M m+M a$ & Ia 15 & 24 & 10 & 29 & 49 \\
\hline
\end{tabular}


spectively. Percent survival data were arcsine-transformed prior to analysis to meet the assumption of normality. All measures of dispersion reported in this paper are 1 SE of the mean, unless otherwise noted. One-way ANOVAs were used to determine significant differences among bivalve assemblages in tank-level clearance rates, and post hoc Tukey's HSD tests were performed to determine significant differences between assemblage pairs. Chi-squared tests were employed to determine whether clearance rates for focal bivalve species within the given multispecies assemblage were additive. Finally, linear regressions were used to determine whether species richness had a significant effect on the clearance rates of assemblages and the productivity of given focal species across assemblages.

\section{RESULTS}

\subsection{Clearance rates of cultured algae: Pavlova lutheri}

The species richness of an assemblage had no effect on the clearance rate of $P$. lutheri (linear regression, $\mathrm{r}^{2}<0.01 \mathrm{p}=0.40$, Fig. 2A). On average, bivalve assemblages cleared the tanks of $P$. lutheri at a rate of $22.0 \pm 3.88 \mathrm{l} \mathrm{h}^{-1}$ (Figs. 2A \& 3A). When supplied with $P$. lutheri, the clearance rates of each focal species within any given multispecies assemblage were additive (chi-squared: $0.004 \leq x \leq 0.260, \mathrm{df}=1,0.61 \leq$ $\mathrm{p} \leq 0.95$, Fig. 3A). For example, the tank-level clearance rate for $P$. lutheri in oyster and surfclam monocultures was $15.5 \pm 2.77$ and $21.6 \pm 5.321 \mathrm{~h}^{-1}$, respectively. The tank-level clearance rate for the oyster/surfclam biculture, which contained half as many individuals as each monoculture, was $18.1 \pm$ $5.71 \mathrm{l} \mathrm{h}^{-1}$.

\subsection{Clearance rates of cultured algae: P. lutheri and Nannochloropsis oculata}

When supplied a 2-species mixture of cultured algae, all assemblages demonstrated greater clearance rates for the larger microalga, $P$. lutheri, compared to the smaller N. oculata (Fig. 4); however, none exhibited a significant preference (paired $t$-test: $1.1 \leq t \leq 4.2, \mathrm{df}=2,0.05<\mathrm{p}<0.42$ ). The species richness of an assemblage had no effect on the clearance rate of either microalga ( $P$. lutheri-linear regression, $\mathrm{r}^{2}<0.01 \mathrm{p}=0.62$, Fig. $2 \mathrm{~B} ; N$. oculata - linear regression, $\mathrm{r}^{2}<0.01 \mathrm{p}=0.58$, Fig. 2B). On average, when

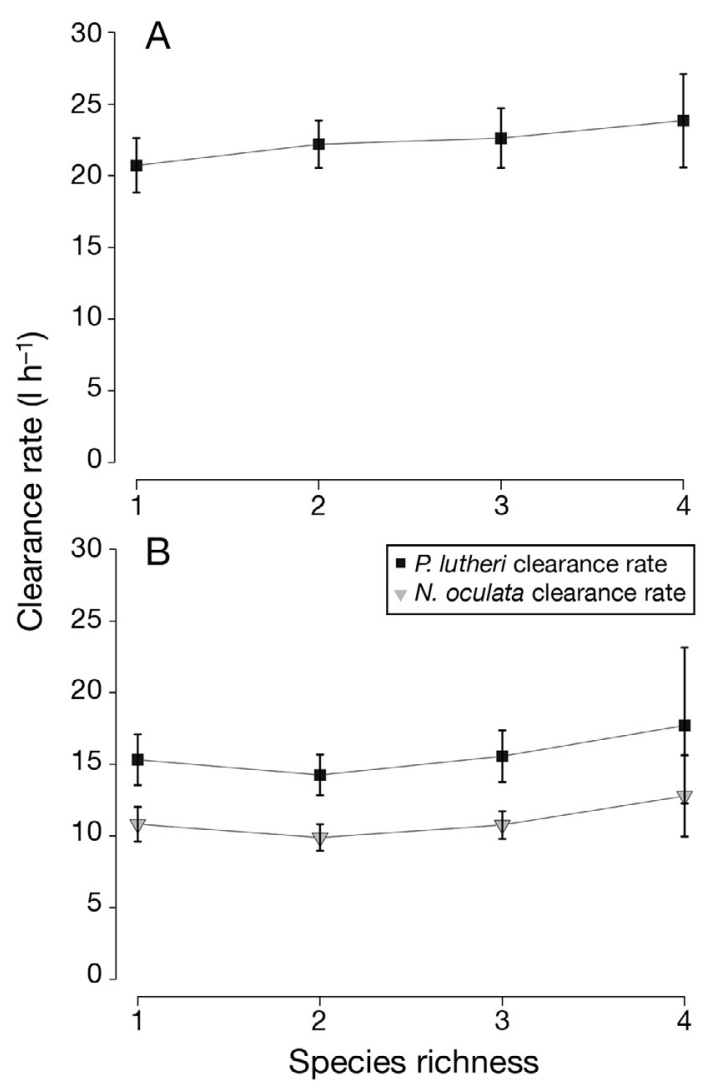

Fig. 2. Effect of species richness on tank-level clearance of cultured microalgae. Particle clearance rates of bivalve assemblage when supplied with (A) only Pavlova lutheri or (B) a mixture of P. lutheri and Nannochloropsis oculata. Points represent mean values and error bars represent SEM. For each curve, $\mathrm{N}=12$ replicate monoculture mesocosms, $\mathrm{N}=18$ biculture mesocosms, $\mathrm{N}=12$ triculture mesocosms, and $\mathrm{N}=3$ four-species polyculture mesocosms

the bivalve assemblages were provided the algal mixture, they cleared the tanks of $P$. lutheri and $N$. oculata at rates of $15.1 \pm 3.56$ and $10.6 \pm 2.22 \mathrm{l} \mathrm{h}^{-1}$, respectively. When averaged across all assemblages, tank-level clearance rate for all particles was $25.7 \pm$ $5.50 \mathrm{l} \mathrm{h}^{-1}$ (Figs. 2B \& 3B).

When supplied with the mixture of $P$. lutheri and $N$. oculata, the clearance rates of each focal bivalve species within any given multispecies assemblage were additive $\left(P\right.$. lutheri chi-squared: $3 \times 10^{-5} \leq x \leq 0.298$, $\mathrm{df}=1,0.59 \leq \mathrm{p} \leq 0.99 ; N$. oculata chi-squared: $6 \times 10^{-5}$ $\leq x \leq 1.184, \mathrm{df}=1,0.28 \leq \mathrm{p} \leq 0.99$, Fig. 3B). This additive effect of bivalve clearance rates is again best demonstrated by the oyster/surfclam biculture. Oyster and surfclam monocultures cleared $P$. lutheri from the mixture at rates of $15.0 \pm 5.34$ and $15.5 \pm 7.20 \mathrm{l}$ $\mathrm{h}^{-1}$, and cleared $N$. oculata from the mixture at rates of $6.87 \pm 2.28$ and $13.0 \pm 4.42 \mathrm{l} \mathrm{h}^{-1}$, respectively. The 


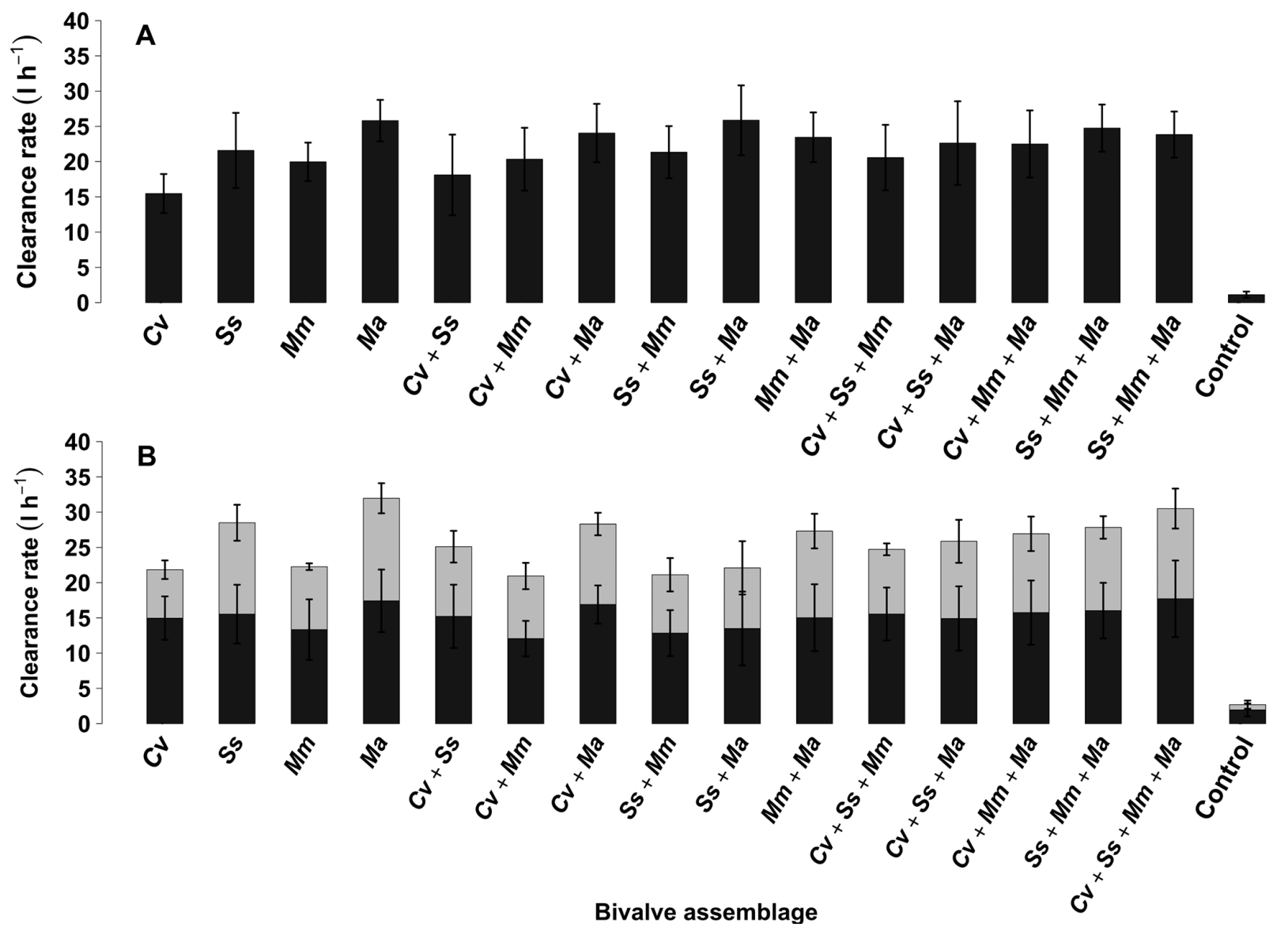

Fig. 3. Tank-level clearance rates of cultured microalgae. Particle clearance rates of bivalve assemblage when supplied with (A) only Pavlova lutheri or (B) a mixture of P. lutheri (dark bars) and Nannochloropsis oculata (light bars). Bars represent mean clearance rates of 3 replicate mesocosms and error bars represent SEM. Cv: Crassostrea virginica, Ss: Spisula solidissima, Mm: Mercenaria mercenaria, Ma: Mya arenaria

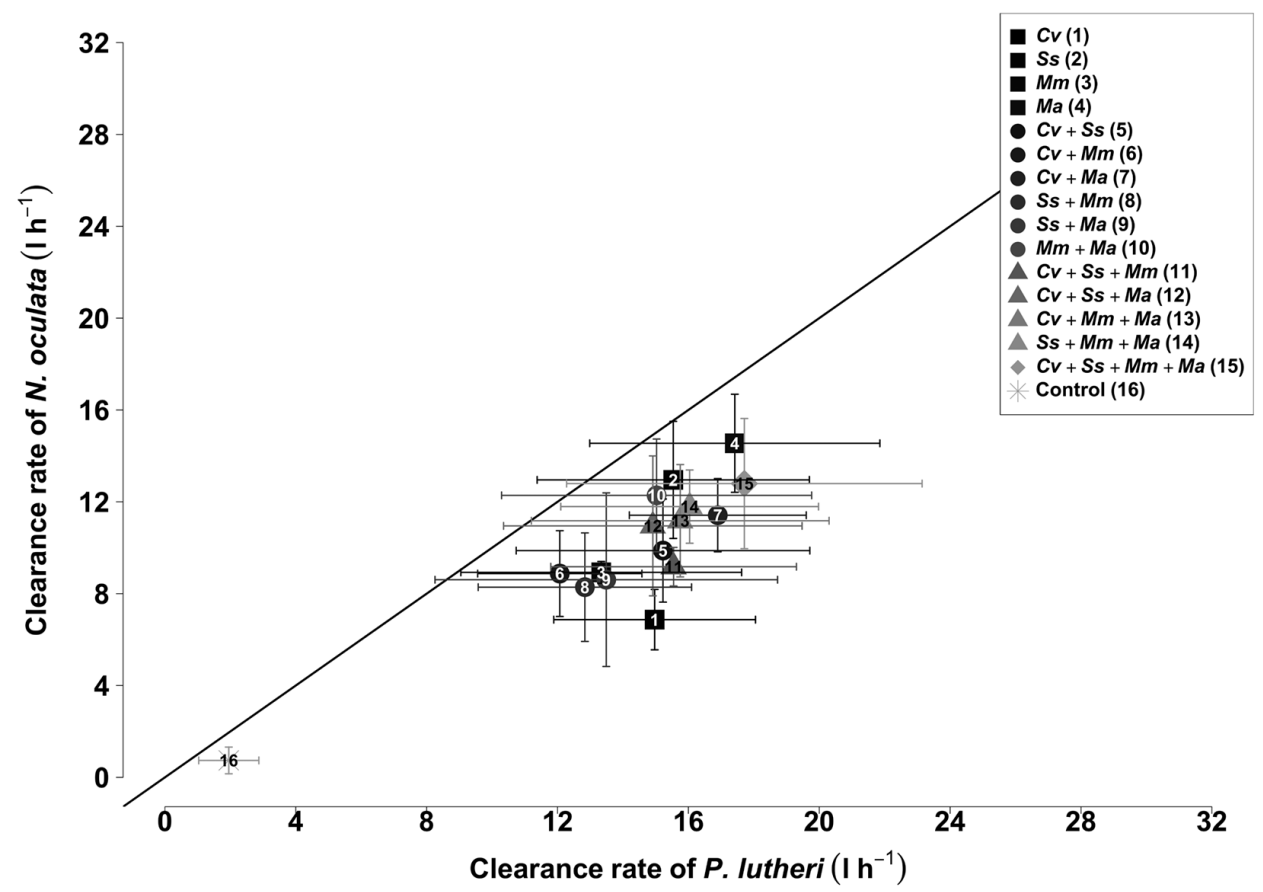

Fig. 4. Clearance of Pavlova lutheri plotted against clearance of Nannochloropsis oculata for each bivalve assemblage. Points represent mean clearance rates of 3 replicate mesocosms and error bars represent SEM. The diagonal line denotes the one-to-one line of equal clearance. Species abbreviations as in Fig. 3 
oyster/surfclam biculture, which again contained half as many individuals as each monoculture, depleted $P$. lutheri and $N$. oculata from the mixture at rates of $15.2 \pm 7.77$ and $9.88 \pm 3.89 \mathrm{l} \mathrm{h}^{-1}$, respectively.

\subsection{Clearance rates of seawater containing natural seston}

Small particles, $\leq 25 \mu \mathrm{m}$, comprised $99.1 \%$ of all particles across samples; larger particles ranging from 25 to $299 \mu \mathrm{m}$ made up the remaining $0.9 \%$. Among the small particles, $82.5 \%$ were $\leq 6 \mu \mathrm{m}$. The tank-level clearance rate for particles $\leq 6 \mu \mathrm{m}$ varied significantly among bivalve assemblages (ANOVA, $F_{5,12}=30.77, \mathrm{p}<0.001$, Fig. 5A). Most notably, the 4 species polyculture exhibited significantly greater clearance rates than the oyster, hard clam, and softshell clam monocultures (Tukey's HSD, $\mathrm{p} \leq 0.006$, Fig. 5A). The polyculture tank-level clearance rate was $61 \%$ greater than the oyster monoculture, $141 \%$ greater than the hard clam monoculture, and $91 \%$ greater than the softshell clam monoculture. Although the polyculture exhibited a mean clearance rate $26 \%$ greater than that of the surfclam monoculture, no significant difference was observed between the pair (Tukey's HSD, $p=0.19$, Fig. 5A). There was also no significant difference in tank-level clearance rate among the oyster, hard clam, and softshell clam monocultures (Tukey's HSD, $\mathrm{p}=0.19$, Fig. 5A). The surfclam monoculture outperformed the other clam monocultures (Tukey's HSD, $p \leq 0.05$, Fig. 5A), but not the oyster monoculture (Tukey's HSD, $p=0.35$, Fig. 5A).

Tank-level clearance rates were also calculated for subsets of particles smaller than $6 \mu \mathrm{m}$ (Table 4). Tank-level clearance rate declined with particle size, but in general, the same statistical trends emerged as when these size classes were grouped (Table 4). However, 2 exceptions were documented. For particles $\leq 3 \mu \mathrm{m}$, the softshell clam monoculture performed statistically similarly to the surfclam monoculture (Tukey's HSD, $0.06<\mathrm{p} \leq 0.09$, Table 4). For the smallest subset of particles, hard clam tank-level clearance was not different from the control mesocosms (Tukey's HSD, $p=0.07$, Table 4).

The same trends for particles $\leq 6 \mu \mathrm{m}$ were similarly observed for tank-level clearance rates of all particles up to $25 \mu \mathrm{m}$ in size (ANOVA, $F_{5,12}=35.85, \mathrm{p}<$ 0.001, Fig. 5B). However, a different trend emerged for particles $>25 \mu \mathrm{m}$. Only the surfclam and hard clam monocultures significantly reduced more particles than the no-animal controls $\left(\right.$ ANOVA, $F_{5,12}=$
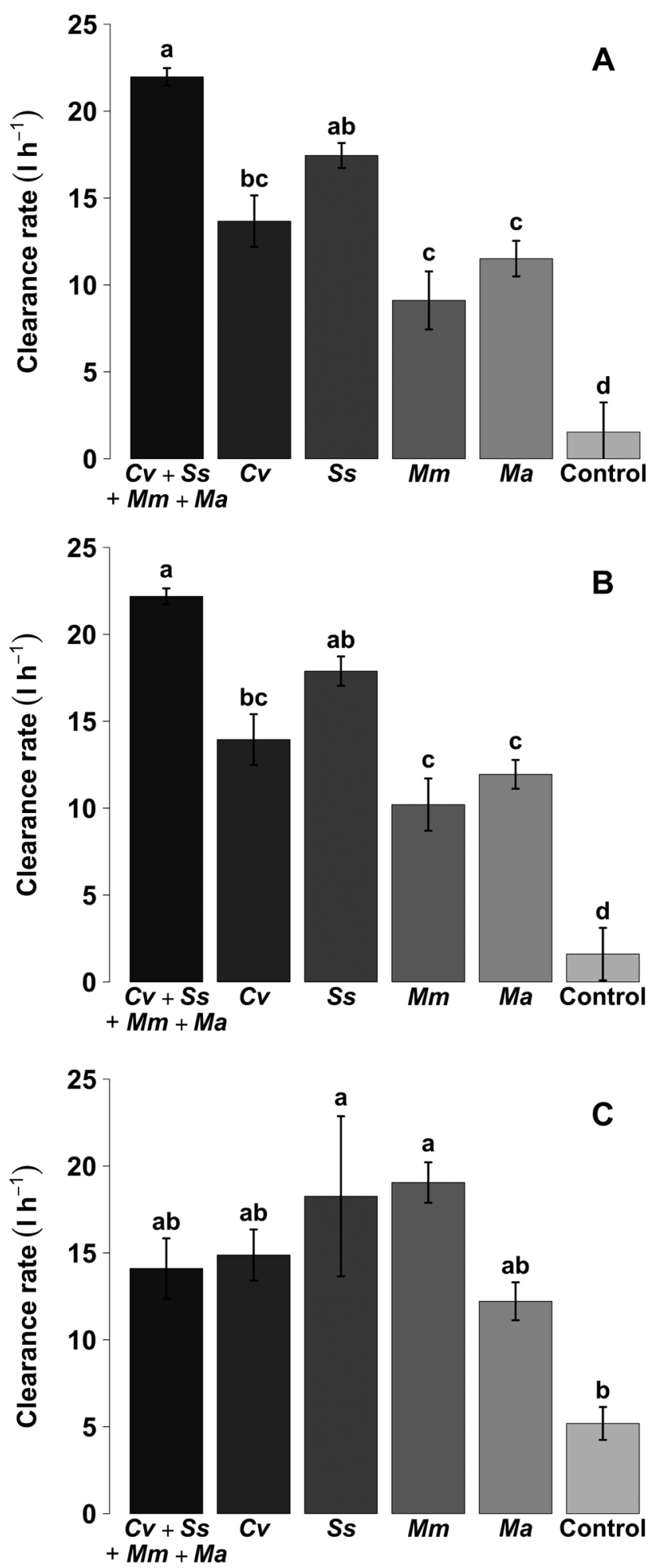

\section{Bivalve assemblage}

Fig. 5. Tank-level clearance rates of natural seston particles for particles sized (A) $\leq 6 \mu \mathrm{m}$, (B) $\leq 25 \mu \mathrm{m}$, and $(\mathrm{C})>25 \mu \mathrm{m}$. Bars represent mean clearance rate of 3 replicate mesocosms and error bars represent SEM. Bars sharing a letter are statistically similar $(\mathrm{p} \leq 0.05)$. Species abbreviations as in Fig. 3 
Table 4. Tank-level clearance rates $\left(\mathrm{l} \mathrm{h}^{-1}\right)$ of natural seston particles sized $\leq 6 \mu \mathrm{m}$. Values are mean \pm SE for 3 replicate mesocosms. Different letters within the same columns indicate significant differences $(\mathrm{p}<0.05)$. Assemblage abbreviations as in Table 3

\begin{tabular}{|c|c|c|c|c|c|c|}
\hline \multirow{2}{*}{ Assemblage } & \multicolumn{6}{|c|}{ - Particle size $(\mu \mathrm{m})$} \\
\hline & $\leq 2$ & $2-3$ & $3-4$ & $4-5$ & $5-6$ & $\leq 6$ \\
\hline$C v+S s+M m+M a$ & $20.6 \pm 0.49 a$ & $24.3 \pm 0.76 \mathrm{a}$ & $25.4 \pm 0.61 \mathrm{a}$ & $24.7 \pm 0.35 \mathrm{a}$ & $25.6 \pm 0.39 a$ & $22.0 \pm 0.50 \mathrm{a}$ \\
\hline $\mathrm{CV}$ & $13.1 \pm 1.45 \mathrm{bc}$ & $14.5 \pm 1.65 \mathrm{bc}$ & $15.1 \pm 1.65 \mathrm{bc}$ & $15.2 \pm 1.52 \mathrm{bc}$ & $16.4 \pm 1.34 \mathrm{bc}$ & $13.7 \pm 1.48 \mathrm{bc}$ \\
\hline Ss & $16.4 \pm 0.58 \mathrm{ab}$ & $19.1 \pm 1.09 \mathrm{ab}$ & $20.3 \pm 0.93 \mathrm{ab}$ & $20.3 \pm 1.12 \mathrm{ab}$ & $20.6 \pm 1.73 \mathrm{ab}$ & $17.4 \pm 0.72 \mathrm{ab}$ \\
\hline$M m$ & $7.8 \pm 1.44 \mathrm{dc}$ & $10.3 \pm 2.48 \mathrm{c}$ & $12.0 \pm 2.06 \mathrm{C}$ & $12.6 \pm 2.00 \mathrm{C}$ & $14.0 \pm 1.85 \mathrm{C}$ & $9.11 \pm 1.67 \mathrm{C}$ \\
\hline Ma & $10.7 \pm 1.18 \mathrm{bc}$ & $12.5 \pm 0.93 \mathrm{bc}$ & $13.7 \pm 0.58 \mathrm{c}$ & $13.6 \pm 0.77 \mathrm{c}$ & $13.7 \pm 0.93 \mathrm{c}$ & $11.5 \pm 1.02 \mathrm{C}$ \\
\hline Control & $2.09 \pm 1.85 \mathrm{~d}$ & $-0.27 \pm 1.67 \mathrm{~d}$ & $1.25 \pm 1.41 \mathrm{~d}$ & $1.29 \pm 1.41 \mathrm{~d}$ & $1.00 \pm 1.33 \mathrm{~d}$ & $1.54 \pm 1.70 \mathrm{~d}$ \\
\hline
\end{tabular}

5.041, p $\leq$ 0.01, Fig. 5C); no significant differences in tank-level clearance rates were observed across bivalve assemblages (Tukey's HSD, p >0.31, Fig. 5C).

\subsection{Effect of species diversity on productivity}

Generally, the composition of the bivalve assemblages had no effect on individual bivalve growth.
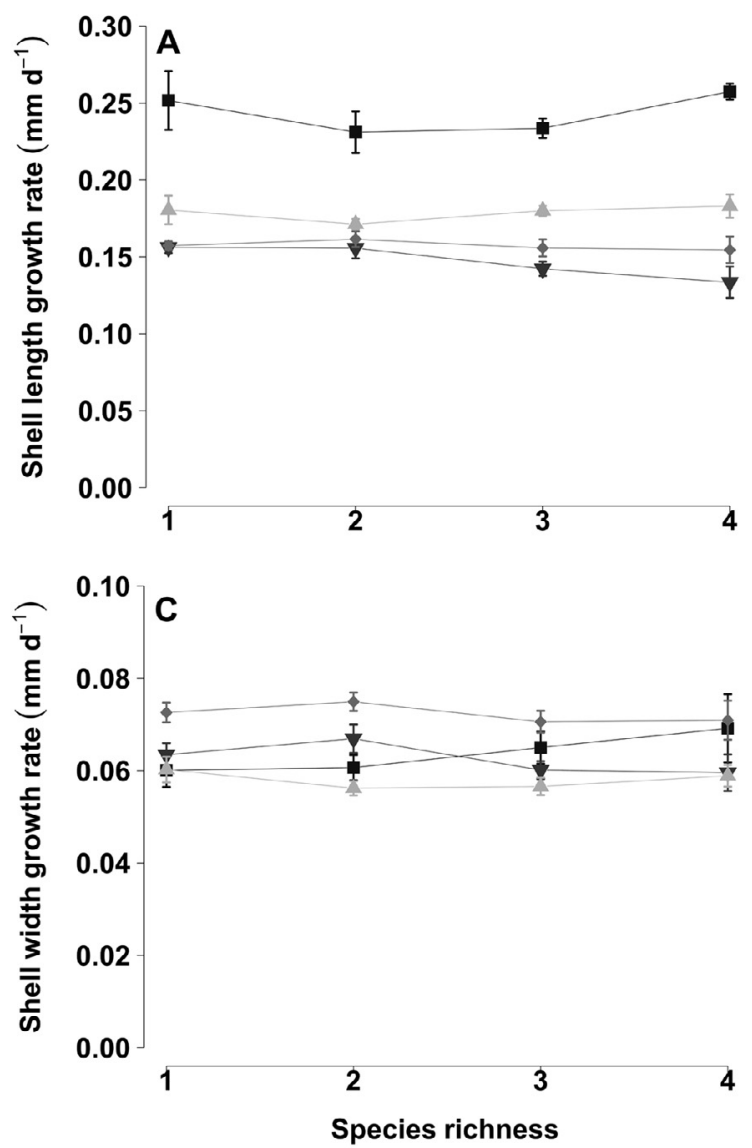

Average daily growth rates for shell length (Fig. 6A), shell height (Fig. 6B), shell width (Fig. 6C), and whole wet weight (Fig. 6D) remained constant for each focal species, regardless of the species richness of an assemblage (linear regression, $\mathrm{r}^{2}<0.07, \mathrm{p}>$ 0.11 , Table 5). The only exception was a slight, yet significant negative effect observed for surfclam shell length (linear regression, $r^{2}=0.17, p<0.03$, Fig. 6A, Table 5).
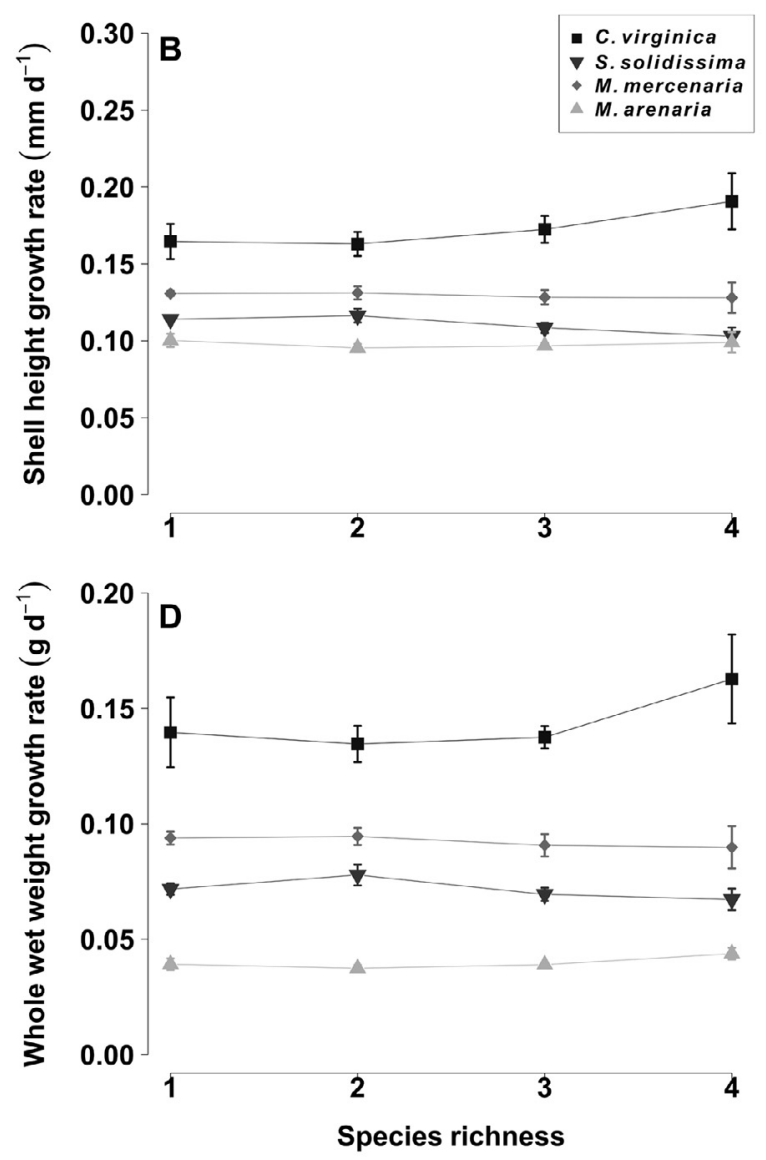

Fig. 6. Effect of species richness on bivalve productivity in terms of average daily growth rates of (A) shell length, (B) shell height, (C) shell width, and (D) whole wet weight. Points represent mean values and error bars represent SEM. For each focal species, $\mathrm{N}=3$ for monocultures, $\mathrm{N}=9$ for bicultures, $\mathrm{N}=9$ for tricultures, and $\mathrm{N}=3$ for 4 -species polyculture 
Table 5. Results of linear regressions of various productivity metrics on bivalve assemblage species richness. Bold represents statistically significant values $(p<0.05)$. Assemblage abbreviations as in Table 3

\begin{tabular}{|c|c|c|c|c|c|c|}
\hline $\begin{array}{l}\text { Spe- } \\
\text { cies }\end{array}$ & $\begin{array}{l}\text { Productivity } \\
\text { metric }\end{array}$ & $\mathrm{p}$ & $\begin{array}{l}\text { Adjusted } \\
\mathrm{r}^{2}\end{array}$ & $m$ & $b$ & $F_{1,22}$ \\
\hline$C_{V}$ & Shell length & 0.776 & -0.042 & 0.0021 & 0.23 & 0.083 \\
\hline Ss & Shell length & 0.025 & 0.17 & -0.0090 & 0.17 & 5.77 \\
\hline $\mathrm{Mm}$ & Shell length & 0.546 & -0.028 & -0.0021 & 0.16 & 0.38 \\
\hline Ma & Shell length & 0.301 & 0.0052 & 0.0028 & 0.17 & 1.12 \\
\hline$C V$ & Shell height & 0.138 & 0.056 & 0.0089 & 0.15 & 2.37 \\
\hline SS & Shell height & 0.074 & 0.10 & -0.0047 & 0.12 & 3.52 \\
\hline $\mathrm{Mm}$ & Shell height & 0.640 & -0.035 & -0.0014 & 0.13 & 0.23 \\
\hline Ma & Shell height & 0.993 & -0.045 & 0.000015 & 0.10 & 0.000081 \\
\hline$C_{V}$ & Shell width & 0.135 & 0.058 & 0.0072 & 0.051 & 0.80 \\
\hline SS & Shell width & 0.139 & 0.056 & -0.0027 & 0.070 & 2.36 \\
\hline$M m$ & Shell width & 0.325 & 0.00063 & -0.0015 & 0.076 & 1.02 \\
\hline Ma & Shell width & 0.841 & -0.044 & -0.00024 & 0.058 & 0.041 \\
\hline $\mathrm{CV}$ & Whole wet weight & 0.227 & 0.023 & 0.0065 & 0.12 & 1.54 \\
\hline SS & Whole wet weight & 0.211 & 0.028 & -0.0032 & 0.081 & 1.66 \\
\hline $\mathrm{Mm}$ & Whole wet weight & 0.494 & -0.023 & -0.0020 & 0.10 & 0.48 \\
\hline Ma & Whole wet weight & 0.117 & 0.067 & 0.0015 & 0.035 & 2.67 \\
\hline$C V$ & Survival & 0.132 & 0.059 & 0.069 & 1.18 & 2.45 \\
\hline Ss & Survival & 0.228 & 0.023 & -0.093 & 1.39 & 1.54 \\
\hline$M m$ & Survival & 0.096 & 0.081 & 0.068 & 1.28 & 3.02 \\
\hline Ma & Survival & 0.612 & -0.033 & -0.020 & 1.17 & 0.26 \\
\hline
\end{tabular}

Across assemblages, oysters exhibited the greatest average daily growth rate for each of the parameters measured. On average, oyster shell lengths, heights, and widths grew at $0.24 \pm 0.0061,0.17 \pm 0.0051$, and $0.060 \pm 0.0019 \mathrm{~mm} \mathrm{~d}^{-1}$, respectively; oyster wet weights increased by $0.14 \pm 0.0046 \mathrm{~g} \mathrm{~d}^{-1}$ (Table 6). The 3 clam species exhibited remarkably similar growth rates across all measured parameters (Table 6). For instance, the average daily shell length growth rate for surfclams, hard clams, and softshell clams was $0.15 \pm 0.0036,0.16 \pm 0.0030$, and $0.18 \pm$ $0.0023 \mathrm{~mm} \mathrm{~d}^{-1}$, respectively (Table 6).

Over the $93 \mathrm{~d}$ experiment, survival of the focal bivalves was high and varied little among replicates. The species richness of an assemblage had no effect on the survival of the focal bivalves (linear regression, $\mathrm{r}^{2}<0.08, \mathrm{p}>0.09$, Table 5). Hard clam survival was highest at $98 \pm 0.69 \%$, and oyster survival was similarly high at $96 \pm 0.94 \%$ (Table 6). Both the softshell clam and surfclam survival were lower, with softshell clam survival at $89 \pm 1.4 \%$ and surfclam survival lowest at $87 \pm 3.7 \%$ (Table 6 ). A notable outlier was surfclam survival in the oyster/surfclam/hard clam assemblages; at $54 \pm 22 \%$, this combination represents the lowest and most variable survival for any species in any combination. This stands in contrast to the mean survival of hard clams, oysters, and softshell clams, which never fell below 92, 90, and $81 \%$, respectively, for any assemblage (Table 6).

\section{DISCUSSION}

Niche complementarity predicts that diverse bivalve assemblages would filter more particles and exhibit greater productivity if the species in the assemblage use different resources (Schoener 1974, Chesson 2000). Although our results failed to detect this trend when assemblages were supplied cultured algae, we did detect enhanced particle clearance rates when the same experiments were conducted using natural seston. The focal bivalves of this study exhibit flexible diets, consuming picoplankton, mesozooplankton, and detritus as supplements to their main nutritional source, phytoplankton (Matthiessen 1960, Kreeger et al. 1988, Prins \& Escaravage 2005, Kach \& Ward 2008). Unlike the cultured algae experiments, where bivalve mixtures were competing for only 1 or 2 algal species, the diversity of food available in the natural seston experiment provided the conditions necessary to observe resource partitioning among Crassostrea virginica, Spisula solidissima, Mercenaria mercenaria, and Mya arenaria. However, results from the productivity experiment show that growth was not enhanced in diverse assemblages, suggesting that clearance rate and productivity are decoupled. Nevertheless, we conclude that bivalve farms will benefit from growing a diverse set of crops, because in nearly every case, bivalve co-culture did not compromise growth for any component species in a multispecies group.

\subsection{Effect of species diversity on particle clearance}

We anticipated that if niche complementarity occurred among the focal bivalves, more diverse assemblages would show higher particle clearance rates. However, our results only demonstrated this increase in clearance with diversity when natural seston was supplied. In the cultured algae experiments, clearance rates of each focal bivalve species within any given multispecies assemblage were additive. This finding suggests that the allometric equations used in this study adequately related a bivalve's size to its clearance rate, despite some differences in the methodology used by the listed 
Table 6. Species-specific productivity across bivalve assemblages. Values are mean \pm SE for 3 replicate mesocosms. Focal species within assemblages are bolded. Assemblage abbreviations as in Table 3

\begin{tabular}{|c|c|c|c|c|c|}
\hline \multirow[t]{2}{*}{ Assemblage } & \multicolumn{4}{|c|}{ Average daily growth rates } & \multirow{2}{*}{$\begin{array}{c}\text { Survival } \\
(\%)\end{array}$} \\
\hline & $\begin{array}{l}\text { Shell length } \\
\left(\mathrm{mm} \mathrm{d}^{-1}\right)\end{array}$ & $\begin{array}{l}\text { Shell height } \\
\left(\mathrm{mm} \mathrm{d}^{-1}\right)\end{array}$ & $\begin{array}{l}\text { Shell width } \\
\left(\mathrm{mm} \mathrm{d}^{-1}\right)\end{array}$ & $\begin{array}{c}\text { Whole wet } \\
\text { weight }\left(\mathrm{g} \mathrm{d}^{-1}\right)\end{array}$ & \\
\hline$C \boldsymbol{V}$ & $0.25 \pm 0.019$ & $0.16 \pm 0.011$ & $0.060 \pm 0.0036$ & $0.14 \pm 0.015$ & $98 \pm 0.33$ \\
\hline $\boldsymbol{C V}+S s$ & $0.27 \pm 0.015$ & $0.18 \pm 0.010$ & $0.066 \pm 0.0027$ & $0.16 \pm 0.016$ & $92 \pm 3.9$ \\
\hline $\boldsymbol{C} \boldsymbol{v}+\mathrm{Mm}$ & $0.21 \pm 0.019$ & $0.16 \pm 0.013$ & $0.055 \pm 0.0040$ & $0.12 \pm 0.0079$ & $95 \pm 2.3$ \\
\hline $\boldsymbol{C v}+M a$ & $0.21 \pm 0.015$ & $0.15 \pm 0.014$ & $0.060 \pm 0.0060$ & $0.13 \pm 0.0088$ & $90 \pm 3.3$ \\
\hline $\boldsymbol{C V}+S S+M m$ & $0.24 \pm 0.0081$ & $0.18 \pm 0.019$ & $0.072 \pm 0.0063$ & $0.13 \pm 0.0047$ & $98 \pm 1.7$ \\
\hline $\boldsymbol{C v}+S s+M a$ & $0.23 \pm 0.016$ & $0.16 \pm 0.018$ & $0.058 \pm 0.0062$ & $0.14 \pm 0.013$ & $98 \pm 1.7$ \\
\hline $\boldsymbol{C v}+M m+M a$ & $0.23 \pm 0.013$ & $0.18 \pm 0.011$ & $0.065 \pm 0.0045$ & $0.14 \pm 0.0075$ & $97 \pm 1.7$ \\
\hline $\boldsymbol{C v}+S s+M m+M a$ & $0.26 \pm 0.0052$ & $0.19 \pm 0.018$ & $0.069 \pm 0.0074$ & $0.16 \pm 0.019$ & $98 \pm 2.3$ \\
\hline Ss & $0.16 \pm 0.0038$ & $0.11 \pm 0.0018$ & $0.064 \pm 0.0025$ & $0.072 \pm 0.0025$ & $98 \pm 1.2$ \\
\hline$C V+\boldsymbol{S s}$ & $0.15 \pm 0.0071$ & $0.11 \pm 0.0046$ & $0.062 \pm 0.0026$ & $0.070 \pm 0.0039$ & $87 \pm 3.8$ \\
\hline $\mathbf{S} \boldsymbol{s}+\mathrm{Mm}$ & $0.17 \pm 0.0096$ & $0.13 \pm 0.0066$ & $0.076 \pm 0.0024$ & $0.088 \pm 0.0074$ & $97 \pm 2.4$ \\
\hline $\boldsymbol{S s}+\mathbf{M a}$ & $0.15 \pm 0.015$ & $0.11 \pm 0.0075$ & $0.063 \pm 0.0067$ & $0.075 \pm 0.0094$ & $94 \pm 0.0$ \\
\hline$C v+\boldsymbol{S} \boldsymbol{s}+M m$ & $0.14 \pm 0.0098$ & $0.11 \pm 0.0078$ & $0.058 \pm 0.0036$ & $0.062 \pm 0.0049$ & $54 \pm 22$ \\
\hline$C V+\boldsymbol{S} \boldsymbol{s}+M a$ & $0.14 \pm 0.012$ & $0.11 \pm 0.0073$ & $0.061 \pm 0.0049$ & $0.074 \pm 0.0047$ & $86 \pm 2.3$ \\
\hline $\boldsymbol{S} \boldsymbol{s}+\mathbf{M m}+\mathbf{M a}$ & $0.15 \pm 0.0035$ & $0.11 \pm 0.0031$ & $0.062 \pm 0.0016$ & $0.073 \pm 0.0032$ & $93 \pm 5.9$ \\
\hline$C v+\boldsymbol{S s}+M m+M a$ & $0.13 \pm 0.010$ & $0.10 \pm 0.0058$ & $0.060 \pm 0.0040$ & $0.067 \pm 0.0047$ & $92 \pm 4.9$ \\
\hline Mm & $0.16 \pm 0.0026$ & $0.13 \pm 0.0017$ & $0.073 \pm 0.0021$ & $0.094 \pm 0.0028$ & $99 \pm 0.67$ \\
\hline$C v+M m$ & $0.15 \pm 0.012$ & $0.12 \pm 0.0069$ & $0.071 \pm 0.0045$ & $0.087 \pm 0.0077$ & $98 \pm 1.7$ \\
\hline$S S+M m$ & $0.17 \pm 0.0047$ & $0.14 \pm 0.0035$ & $0.080 \pm 0.0025$ & $0.11 \pm 0.0013$ & $97 \pm 1.7$ \\
\hline $\mathbf{M m}+M a$ & $0.16 \pm 0.0065$ & $0.13 \pm 0.0082$ & $0.074 \pm 0.00070$ & $0.091 \pm 0.0022$ & $92 \pm 1.7$ \\
\hline$C V+S s+M m$ & $0.14 \pm 0.0097$ & $0.12 \pm 0.0078$ & $0.065 \pm 0.0041$ & $0.079 \pm 0.0085$ & $100 \pm 0.0$ \\
\hline$C v+\mathbf{M m}+M a$ & $0.16 \pm 0.0092$ & $0.13 \pm 0.0051$ & $0.073 \pm 0.0032$ & $0.094 \pm 0.0033$ & $97 \pm 2.7$ \\
\hline $\mathbf{S s}+\mathbf{M m}+\mathbf{M a}$ & $0.17 \pm 0.0091$ & $0.14 \pm 0.0096$ & $0.074 \pm 0.0041$ & $0.10 \pm 0.0083$ & $100 \pm 0.0$ \\
\hline$C v+S s+M m+M a$ & $0.15 \pm 0.0086$ & $0.13 \pm 0.0099$ & $0.071 \pm 0.0043$ & $0.090 \pm 0.0092$ & $100 \pm 0.0$ \\
\hline Ma & $0.18 \pm 0.0093$ & $0.10 \pm 0.0043$ & $0.060 \pm 0.0028$ & $0.039 \pm 0.0025$ & $93 \pm 3.2$ \\
\hline$C V+M a$ & $0.16 \pm 0.0083$ & $0.09 \pm 0.0046$ & $0.052 \pm 0.0028$ & $0.034 \pm 0.0025$ & $86 \pm 1.5$ \\
\hline$S s+\mathbf{M a}$ & $0.17 \pm 0.0043$ & $0.10 \pm 0.0037$ & $0.060 \pm 0.0019$ & $0.040 \pm 0.00020$ & $85 \pm 7.0$ \\
\hline$M m+\mathbf{M a}$ & $0.18 \pm 0.0027$ & $0.10 \pm 0.0027$ & $0.056 \pm 0.0024$ & $0.038 \pm 0.0029$ & $93 \pm 2.0$ \\
\hline$C V+S s+M a$ & $0.17 \pm 0.0016$ & $0.09 \pm 0.0016$ & $0.050 \pm 0.0018$ & $0.036 \pm 0.00020$ & $90 \pm 3.3$ \\
\hline$C v+M m+\mathbf{M a}$ & $0.18 \pm 0.0027$ & $0.10 \pm 0.0028$ & $0.061 \pm 0.0023$ & $0.042 \pm 0.0019$ & $81 \pm 3.8$ \\
\hline$S s+M m+\mathbf{M a}$ & $0.19 \pm 0.0039$ & $0.10 \pm 0.0042$ & $0.059 \pm 0.0010$ & $0.040 \pm 0.00020$ & $91 \pm 3.0$ \\
\hline$C v+S s+M m+\mathbf{M a}$ & $0.18 \pm 0.0076$ & $0.10 \pm 0.0066$ & $0.059 \pm 0.0023$ & $0.044 \pm 0.0025$ & $91 \pm 4.2$ \\
\hline
\end{tabular}

sources from which the equations were derived. Additive clearance rates of the focal species were observed when the assemblages were supplied solely with Pavlova lutheri as well as when they were supplied a mixture of $P$. lutheri and Nannochloropsis oculata. When provided both microalgae, all communities had slightly greater clearance rates of $P$. lutheri; however, none displayed a significant preference. This result was unexpected given that the capture efficiency of all 4 focal species is known to decrease with size for particles $<6 \mu \mathrm{m}$ (Riisgård 1988). With a diameter between 4 and $6 \mu \mathrm{m}, P$. lutheri cells should be cleared with near complete efficiency. Conversely, $N$. oculata cells are typically $8 \times$ smaller in volume than $P$. lutheri and should be captured considerably less effectively (Riisgård 1988). The near equivalence in clearance rates for these differently sized microalgae presents an intriguing opportunity for further study.
In the natural seston depletion experiments, tank-level clearance was equivalent across all assemblages for particles $>25 \mu \mathrm{m}$. This result reinforces the concept that all 4 focal species can extract particles between 25 and $299 \mu \mathrm{m}$ with near complete efficiency. Beyond large phytoplankton such as diatoms and dinoflagellates, particles in this size class can include detritus and zooplankton. Some suspension-feeding bivalves use these other nutritional sources as a supplement to phytoplankton (Langdon \& Newell 1990, Davenport et al. 2000, Prins \& Escaravage 2005). However, even if large particles are ingested, they may not necessarily be digested (Shumway et al. 1987). Since this study did not examine the extent to which particles were ingested, it is unclear whether the focal species rejected these larger particles as pseudofeces or consumed them, and if so, whether they were actually assimilated. 
Phytoplankton and other organic particles $<25 \mu \mathrm{m}$ are most often associated with preferential bivalve food (Hawkins et al. 1996, Ward et al. 1997, Bacon et al. 1998, Levinton et al. 2002). In our natural seston depletion experiments, the 4 -species polyculture had significantly greater tank-level clearance compared to all monocultures, with the exception of the surfclam monoculture. Interestingly, this trend was also true for particles $<6 \mu \mathrm{m}$, the sizes at which bivalves filter at lower efficiency (Riisgård 1988). The augmentation in particle clearance observed in the 4species polyculture compared to most monocultures suggests that some degree of niche complementarity exists among the focal species. Many studies that have examined niche complementarity have highlighted cases where species with narrow niches support increased diversity and occur in stable coexistence (Pyke 1982, Grant \& Grant 2006, Fox \& Bellwood 2013). However, other studies have found that even species with broad, overlapping niches can promote diversity and coexistence through plasticity in their resource use (Behmer \& Joern 2008, Ashton et al. 2010). Species within the suspension-feeding guild have considerable overlap in the size of particles they can acquire. Yet, some suspension feeders do partition available food resources to minimize interspecific competition (Peterson 1982, Lesser et al. 1992, Kang et al. 2009, Lacoste et al. 2016, Novais et al. 2016). We propose that in this study, the bivalve polyculture removed more suspended seston than monocultures due to variations in particle capture processes and differences in dietary requirements or preferences exhibited by the 4 focal species.

\subsection{Variations in particle capture processes}

Variations in gill structure and function as well as differences in mucus composition are mechanisms by which bivalves may control the efficiency of particle capture. Bivalve gill (ctenidium) morphology and physiology is diverse (Rosa et al. 2018). In this study, the 3 clam species have homorhabdic eulamellibranch gills, while the oyster has heterorhabdic pseudolamellibranch gills (Arakawa 1971). Of these 2 types, eulamellibranch gills are more complex, unified structures that allow more control to be exerted over the flow of water passing by the gills and increase the opportunity for particle capture (Ward et al. 1994, Beninger et al. 1997). Such differences in gill structure and function could be responsible for differences in the observed particle capture efficiency.
Cilia are responsible for pumping water past the gills and collecting particles (Dame 1996). Lateral cilia draw water through the pallial cavity and over the gills (Dame 1996). The currents produced are regulated by species-specific traits and behaviors, including valve gape (Frank et al. 2007), the inhalant siphon aperture size (Jørgensen \& Riisgård 1988, Riisgård et al. 2003), and branchical musculature (Ward et al. 1994, Medler \& Silverman 2001, Gainey et al. 2003). Moreover, interspecific variation in ciliary beating and flow patterns are mediated by environmental conditions; for instance, the presence of the brown tide alga Aureococcus anophagefferen reduced ciliary beating in $C$. virginica and $M$. mercenaria but not $M$. arenaria (Gainey \& Shumway 1991, Robbins et al. 2010). Laterofrontal cilia, or cirri, entrain particles through a combination of mucociliary and hydrodynamic mechanisms (Ward et al. 1994, Dame, 1996, Beninger et al. 1997, Pales Espinosa \& Allam 2018). The size, structure, and spacing of laterofrontal cilia affect the capture efficiency of particles <6 $4 \mathrm{~m}$ (Wright et al. 1982). Riisgård (1988) found that $S$. solidissima, M. mercenaria, and C. virginica all possess laterofrontal cirri and can capture particles as small as $2 \mu \mathrm{m}$ with at least $50 \%$ efficiency, while Argopecten irradians does not and captures those particles with only $15 \%$ efficiency. In our study, C. virginica, $S$. solidissima, and $M$. arenaria were highly efficient at capturing particles in the smallest size class. Monocultures of those 3 species cleared particles $\leq 2 \mu \mathrm{m}$ approximately $80 \%$ as well as they cleared particles between 5 and $6 \mu \mathrm{m}$. By contrast, $M$. mercenaria cleared the smallest particles only $56 \%$ as efficiently.

The efficiency of bivalve suspension-feeding is largely dependent on the mucus that coats the pallial organs (Dufour \& Beninger 2001). Lectins, carbohydrate-binding proteins that are present in mucus, promote preferential particle selection by strongly binding to carbohydrate residues that cover the surfaces of microalgae (Pales Espinosa et al. 2010a,b, 2016a,b). Notably, a lectin that binds to Nannochloropsis sp. but not to $P$. lutheri has been identified in C. virginica (Pales Espinosa \& Allam 2018). This finding may help explain why in this study, the bivalve assemblages cleared $P$. lutheri and $N$. oculata at similar rates despite the difference in particle size. Mucus may also help bivalves discriminate between particles through interactions with other physiochemical properties of seston, such as wettability and surface charge (Solow \& Gallager 1990, Rosa et al. 2017). Generally, microalgae with hydrophobic surfaces and those with a midrange of surface charges 
are preferentially selected over those with more hydrophilic surfaces and those with a neutral charge (Rosa et al. 2013, 2017, 2018). However, different bivalves do not always respond to the same particle surface properties (Rosa et al. 2017). The relationships between bivalve particle selection and the physiochemical properties of seston require further study.

\subsection{Variations in diet requirement or preference}

Many studies have demonstrated that seston characteristics have a significant effect on bivalve clearance rates. Behavioral responses to seston vary across taxa; total seston concentration, the organic content of seston, and its nutritional profile can each influence bivalve feeding patterns (Hawkins et al. 1996, Navarro et al. 2000, Hewitt \& Pilditch 2004, Yahel et al. 2009, Galimany et al. 2013). Generally, clearance declines as the seston concentration increases, although the clearance curves for some species have an initial peak over low to moderate seston concentrations before declining (Hawkins et al. 1999, Velasco \& Navarro 2005). Species that inhabit more turbid environments tend to exhibit greater plasticity in their particle processing mechanisms. In response to seston concentration, some species such as $M$. mercenaria regulate clearance rate, while others like blue mussels Mytilus edulis regulate pseudofeces production (Foster-Smith 1975, Bricelj \& Malouf 1984). Ribbed mussels Geukensia demissa employ multiple strategies; to compensate for the diluted nutritional quality of the seston encountered in a highly turbid and urbanized estuary, ribbed mussels enhanced their pseudofeces production and selection efficiency, thus enriching the particles they ingested with more organic content (Galimany et al. 2013).

Yet beyond the mechanisms that bivalves evolved to cope with the quantity of particles in their environment, variations in particle selection mechanisms likely also arose in response to species-specific dietary requirements. Differential capture of similarly sized, yet more nutritious, particles allows species to increase their feeding efficiency (Cucci et al. 1985, Yahel et al. 2009). Another adaptive strategy, particularly for largely or entirely sessile organisms living in dynamic environments, is to conserve mechanisms that alter a species' diet when food availability changes due to competition or environmental factors. Phytoplankton are the principal source of nutrition for all 4 focal species, yet they also display flexibility in their particle capture selectivity and diet. While their capture efficiencies for picoplankton are low, $C$. virginica and $M$. mercenaria will consume them when other food is scarce (Kreeger et al. 1988, Langdon \& Newell 1990, Kach \& Ward 2008). M. arenaria do not capture bacterioplankton $<1 \mu \mathrm{m}$ effectively (Wright et al. 1982), but will consume slightly larger detritus (Matthiessen 1960). S. solidissima are voracious consumers, and population models suggest wild surfclam stocks are consuming other food beyond that which can be measured as water column primary productivity (Munroe et al. 2013). Farmed surfclams require the fall algal bloom to recover from the stress they encounter during the summer. Since the natural seston depletion experiment occurred in October, we hypothesize that surfclams increased their feeding efficiency during this time. Consequently, the surfclam monoculture clearance rate was lower than, but statistically equivalent to, the 4 -species polyculture.

In this study, niche complementarity was observed despite the prevailing view that most suspension-feeding bivalves tend to be opportunistic generalists (Cranford et al. 2011). Plasticity and seasonality in bivalve feeding patterns may accommodate the niche space of multiple members of a community. To elucidate this, more research needs to be conducted on the plasticity and seasonality of particle capture, particle processing, and the dietary requirements and preferences of bivalves outside laboratory contexts.

\subsection{Effect of species diversity on bivalve productivity}

Unlike the particle depletion experiments, where the stocking densities of all experimental mesocosms had equivalent clearance capacities, the clearance capacities of the bivalve assemblages in the productivity experiment varied more widely. The allometric equations used in this study were also derived from controlled laboratory-based studies that were conducted under a limited range of temperatures and seston characteristics, unlike the fluctuating conditions the bivalves of this study experienced. While these represent limitations of the study, some comparisons can still be made. If food were limiting and complementarity for food resources existed, individuals in species-rich assemblages should have exhibited greater productivity than conspecifics grown in monoculture. This phenomenon has been demonstrated in a long-term grassland experiment where diverse communities produced greater biomass than 
monocultures when grown in fields where nutrients were limited (Tilman et al. 2001, 2006). Alternatively, if food were limiting and strong competition for food resources had existed, the species best equipped to acquire and assimilate the resources would grow while the others would languish. Although experimental and observational data suggest that competitive exclusion in bivalves due to interspecific consumptive competition is rare, weaker competitors may exhibit reduced growth rates (Peterson 1992). For example, localized competitive preemption by blue mussels caused cockles Cerastoderma edule to grow to a smaller shell length, have reduced body weight, and experience lower recruitment (Kamermans 1993, Donadi et al. 2013).

If food were not limiting, neither complementarity nor competition among species would be evident; if all individuals in a community are supplied with enough food, the species identity of the community should not influence its collective productivity (Levinton 1972, Lesser et al. 1992, Peterson 1992). Instead, other forces should regulate each species' growth and in turn the productivity of the community. This was demonstrated by Peterson \& Andre (1980), who examined the growth of the deepdwelling infaunal species Sanguinolaria nuttalli. When grown with 2 other species that occupy the same position in the sediment, $S$. nuttalli growth was reduced by $80 \%$. However, when $S$. nuttalli was grown with the shallow-dwelling Protothaca staminea, no impact on growth was noticeable, indicating that competition for space, not food, was the limiting resource. Similarly, Kamermans et al. (1992) found that interspecific competition between $C$. edule and the Baltic clam Macoma balthica was minimal since food was highly available to both species, especially because $M$. balthica can switch from suspension- to deposit-feeding when seston becomes scarce.

In the present study, in almost every case, the species composition of bivalve assemblages had no effect on the rates of growth for any of the shell dimensions or the whole wet weight for any of the 4 focal bivalves. This occurred despite the discrepancies in the assemblages' clearance capacities. It is likely that the mesocosms never experienced food limitation because full water replacement occurred hourly and food densities at this location are relatively high, thus the observed lack of response in productivity. However, increased species richness did have a slight negative effect on the average daily shell length growth rate for surfclams. This result suggests that surfclams succumbed to some degree of interspecific competition despite the lack of effect on other productivity metrics. Competition against surfclams may have been exacerbated by abiotic factors, particularly temperature and seston concentration.

Atlantic surfclams are vulnerable to warm temperature stress and respond by reducing their clearance rate, ingestion rate, and assimilation efficiency, and by slowing or ceasing their growth (Narváez et al. 2015, Hornstein et al. 2018, Acquafredda et al. 2019). The present study occurred during the warmest part of the year (July to October), when temperatures exceeded the thermal maximum of this species (Munroe et al. 2013, 2016, Acquafredda et al. 2019), but not that of the other 3 species (Loosanoff 1958, Kennedy \& Mihursky 1971, Grizzle et al. 2001). Since its ability to acquire and use food becomes compromised during heat stress, the surfclam's competitive ability may have been depressed during portions of this study. Hard clams, softshell clams, and oysters may also have had a competitive advantage over surfclams because those taxa are better adapted to process the high sediment loads they experienced during the productivity experiment (Bricelj \& Malouf 1984, Grizzle \& Morin 1989, Bacon et al. 1998, Suedel et al. 2015). Unlike the other species, which are commonly exposed to high-turbidity conditions in estuaries, the preferred habitats of surfclams are lowturbidity areas of the continental shelf (Merrill \& Ropes 1969, Snelgrove et al. 1998). Elevated seston concentrations create sub-optimal conditions for surfclams, which result in reduced clearance rates, increased pseudofeces production, and decreased ingestion of phytoplankton (Robinson et al. 1984). This study was limited to a few months during the summer and fall, but future experiments should be conducted over a full year and repeated in the field. A longer study would expose the focal species to a wider range of the abiotic factors that influence clearance rate and growth, including temperature (Jørgensen et al. 1990, Kittner \& Riisgård 2005), salinity (Navarro \& Gonzalez 1998), and changes in seston characteristics (Hawkins et al. 1999, Navarro et al. 2000, Hewitt \& Pilditch 2004, Velasco \& Navarro 2005).

Future studies of bivalve polyculture should also measure the net absorption efficiencies and other post-ingestion processes of the focal species, because productivity is constrained by how well the availability and quality of resources match the particular dietary requirements of a given species at a particular time. Bivalves can meet their energy and nutritional demands by regulating feeding and digestive processes, which can sometimes mitigate the effects 
of a limited or low-quality food supply. For instance, by increasing gut residence time, starved blue mussels can achieve absorption efficiencies equivalent to well-fed conspecifics (Hawkins \& Bayne 1984). Similarly, ribbed mussels increased their gut residence time when supplied with high concentrations of seston that contained relatively low nutritional content (Galimany et al. 2013). Interspecific competition, particularly with non-native species, can overwhelm these adaptive post-ingestion processes, thereby constraining growth (Galimany et al. 2017). Yet, seasonal differences in the ways that physiological and competitive processes interact among suspension feeders can also alter these dynamics (Riera et al. 2002).

Although the focal species of our study are native to the same region, they do not all exhibit high growth rates during the same seasons. The oysters, hard clams, and softshell clams grow best in the spring, summer, and fall, while farmed surfclams perform best during the cooler seasons of fall, winter, and spring (Stecher et al. 1996, M. P. Acquafredda unpubl. data). If these species modulate their niches temporally, then the competitive interactions identified in this study may not hold true throughout all periods of the year.

\subsection{Implications for aquaculture}

Although more work around bivalve polyculture is necessary, the results of this study suggest that $C$. virginica, S. solidissima, M. mercenaria, and $M$. arenaria could be co-cultured in the northeastern USA without outcompeting one another. While bivalve monoculture is still largely the norm for this region, some farmers are experimenting with raising multiple species in close proximity to one another ( $\mathrm{J}$. Kramer pers. obs.). Aquaculture used for restoration of filtration services in estuarine and marine environments has mainly utilized monocultures of $C$. virginica (Kreeger et al. 2018). Results from our study suggest that restoration efforts may benefit from deploying a diverse set of native taxa, which may remove more total suspended particles than any single species. Bivalve productivity was not enhanced in multispecies groups, but in almost every case, increased species richness did not have negative consequences for the growth of each species. Importantly, the other bet-hedging benefits of crop diversification still hold true.

Crop diversification gives aquaculture practitioners protection from any individual crop failure linked to natural phenomena. However, some efficiency may be lost when monocultures are abandoned. Growers must also consider the cost of alternate gear types, available space, product processing, and permitting when considering whether diversification is a feasible option for their farms. Until more research is conducted, growers should also be aware that the strength and sign of these species interactions may be modulated by environmental conditions. The degree of niche partitioning or interspecific competition among these bivalves may vary temporally, spatially, or across other environmental dimensions, and this has implications for the stable coexistence of farmed species.

Acknowledgements. This work was supported by a Student Award administered by the New Jersey Aquaculture Innovation Center of Rutgers University. D.M. was partially supported by the USDA National Institute of Food and Agriculture Hatch project accession number 1020831 through the New Jersey Agricultural Experiment Station, Hatch project NJ32140. Additionally, Sea-Bird Scientific generously supplied the water quality monitoring equipment, which M.P.A. was awarded through the 2016 Student Equipment Loan Program. We are grateful to the following people for providing logistical and technical support: Sarah Borsetti, Joseph Caracappa, Nate Morris, Iris Burt, Lisa Calvo, Samantha Gilbert Lynch, Jenn Gius, Jenny Paterno Shinn, Michael Whiteside, Patty Woodruff, Michael De Luca, David Jones, Josh Kiernan, Matthew Neuman, Sean Towers, Dan Acquafredda, and Joseph Ferraro. We are also grateful to the entities which supplied the bivalves used in these experiments: The Downeast Institute, Sweet Amalia's Oyster Farm, and Bill Avery's Quality Bay Clam Company. This project is a part of M.P.A.'s PhD dissertation research, which is supported by Rutgers University through the Haskin Shellfish Research Laboratory, the Department of Ecology, Evolution, and Natural Resources, and the Graduate Program in Ecology and Evolution. Finally, we thank the anonymous reviewers for providing valuable feedback and helping to improve this article.

\section{LITERATURE CITED}

Acquafredda MP, Munroe DM, Ragone Calvo LM, De Luca $M$ (2019) The effect of rearing temperature on the survival and growth of early juvenile Atlantic surfclams (Spisula solidissima). Aquacult Rep 13:100176

Altieri MA, Nicholls CI, Henao A, Lana MA (2015) Agroecology and the design of climate change-resilient farming systems. Agron Sustain Dev 35:869-890

Arakawa KY (1971) Scatological studies of the Bivalvia (Mollusca). Adv Mar Biol 8:307-436

Ashton IW, Miller AE, Bowman, WD, Suding KN (2010) Niche complementarity due to plasticity in resource use: plant partitioning of chemical $\mathrm{N}$ forms. Ecology 91: 3252-3260

*Bacon GS, MacDonald BA, Ward JE (1998) Physiological responses of infaunal (Mya arenaria) and epifaunal (Placopecten magellanicus) bivalves to variations in 
the concentration and quality of suspended particles. I. Feeding activity and selection. J Exp Mar Biol Ecol 219: 105-125

Beal BF, Nault DM, Annis H, Thayer P, Leighton H, Ellis B (2016) Comparative, large-scale field trials along the Maine coast to assess management options to enhance populations of the commercially important soft-shell clam, Mya arenaria L. J Shellfish Res 35:711-727

* Behmer ST, Joern A (2008) Coexisting generalist herbivores occupy unique nutritional feeding niches. Proc Natl Acad Sci USA 105:1977-1982

Beninger PG, Dufour SC, Bourque J (1997) Particle processing mechanisms of the eulamellibranch bivalves Spisula solidissima and Mya arenaria. Mar Ecol Prog Ser 150: 157-169

Bricelj VM, Malouf RE (1984) Influence of algal and suspended sediment concentrations on the feeding physiology of the hard clam Mercenaria mercenaria. Mar Biol 84:155-165

Bricelj VM, Shumway SE (1998) Paralytic shellfish toxins in bivalve molluscs: occurrence, transfer kinetics, and biotransformation. Rev Fish Sci 6:315-383

* Chesson P (2000) Mechanisms of maintenance of species diversity. Annu Rev Ecol Syst 31:343-366

* Chopin T, Cooper JA, Reid G, Cross S, Moore C (2012) Open-water integrated multi-trophic aquaculture: environmental biomitigation and economic diversification of fed aquaculture by extractive aquaculture. Rev Aquacult $4: 209-220$

Coughlan J (1969) The estimation of filtering rate from the clearance of suspensions. Mar Biol 2:356-358

* Coughlan J, Ansell AD (1964) A direct method for determining the pumping rate of siphonate bivalves. J Cons Int Explor Mer 29:205-213

Cranford PJ, Ward EJ, Shumway SE (2011) Bivalve filter feeding: variability and limits of the aquaculture biofilter. In: Shumway SE (ed) Shellfish aquaculture and the environment. Wiley-Blackwell, Oxford, p 81-124

Cucci TL, Shumway SE, Newell RC, Selvin R, Guillard RRL, Yentsch CM (1985) Flow cytometry: a new method for characterization of differential ingestion, digestion and egestion by suspension feeders. Mar Ecol Prog Ser 24: 201-204

Dame RF (1996) Ecology of marine bivalves: an ecosystem approach. CRC Press, Boca Raton, FL

* Davenport J, Smith RJJW, Packer M (2000) Mussels Mytilus edulis: significant consumers and destroyers of mesozooplankton. Mar Ecol Prog Ser 198:131-137

Donadi S, van der Heide T, van der Zee EM, Eklöf JS and others (2013) Cross-habitat interactions among bivalve species control community structure on intertidal flats. Ecology 94:489-498

* Duffy JE, Lefcheck JS, Stuart-Smith RD, Navarrete SA, Edgar GJ (2016) Biodiversity enhances reef fish biomass and resistance to climate change. Proc Natl Acad Sci USA 113:6230-6235

Dufour SC, Beninger PG (2001) A functional interpretation of cilia and mucocyte distributions on the abfrontal surface of bivalve gills. Mar Biol 138:295-309

FAO (2016) The state of world fisheries and aquaculture 2016: contributing to food security and nutrition for all. FAO, Rome

Fargione J, Tilman D, Dybzinski R, Lambers JHR and others (2007) From selection to complementarity: shifts in the causes of biodiversity-productivity relationships in a long-term biodiversity experiment. Proc R Soc B 274: 871-876

Felton A, Nilsson U, Sonesson J, Felton AM and others (2016) Replacing monocultures with mixed-species stands: ecosystem service implications of two production forest alternatives in Sweden. Ambio 45:124-139

* Foster-Smith RL (1975) The effect of concentration of suspension on the filtration rates and pseudofaecal production for Mytilus edulis L., Cerastoderma edule (L.) and Venerupis pullastra (Montagu). J Exp Mar Biol Ecol $17: 1-22$

Fox JW (2005) Interpreting the 'selection effect' of biodiversity on ecosystem function. Ecol Lett 8:846-856

*Fox RJ, Bellwood DR (2013) Niche partitioning of feeding microhabitats produces a unique function for herbivorous rabbitfishes (Perciformes, Siganidae) on coral reefs. Coral Reefs 32:13-23

Frank DM, Hamilton JF, Ward JE, Shumway SE (2007) A fiber optic sensor for high resolution measurement and continuous monitoring of valve gape in bivalve molluscs. J Shellfish Res 26:575-581

* Gainey LF Jr, Shumway SE (1991) The physiological effect of Aureococcus anophagefferens ('brown tide') on the lateral cilia of bivalve mollusks. Biol Bull (Woods Hole) 181:298-306

Gainey LF Jr, Walton JC, Greenberg MJ (2003) Branchial musculature of a venerid clam: pharmacology distribution and innervation. Biol Bull 204:81-95

Galimany E, Rose JM, Dixon MS, Wikfors GH (2013) Quantifying feeding behavior of ribbed mussels (Geukensia demissa) in two urban sites (Long Island Sound, USA) with different seston characteristics. Estuaries Coasts 36: 1265-1273

KGalimany E, Freeman CJ, Lunt J, Domingos A, Sacks P, Walters L (2017) Feeding competition between the native oyster Crassostrea virginica and the invasive mussel Mytella charruana. Mar Ecol Prog Ser 564:57-66

Gaudin ACM, Tolhurst TN, Ker AP, Janovicek K, Tortora C, Martin RC, Deen W (2015) Increasing crop diversity mitigates weather variations and improves yield stability. PLOS ONE 10:e0113261

* Grant PR, Grant BR (2006) Evolution of character displacement in Darwin's finches. Science 313:224-226

* Grizzle RE, Morin PJ (1989) Effect of tidal currents seston and bottom sediments on growth of Mercenaria mercenaria: results of a field experiment. Mar Biol 102:85-93

Grizzle RE, Bricelj VM, Shumway SE (2001) Physiological ecology of Mercenaria mercenaria. In: Kraeuter JN, Castagna M (eds) Biology of the hard clam. Elsevier, New York, NY, p 305-382

Hagan JM, Wilkerson E (2018) How to install a soft-shell clam farm. Manomet Sustainable Economies Program, Brunswick, ME

Hawkins AJS, Bayne BL (1984) Seasonal variation in the balance between physiological mechanisms of feeding and digestion in Mytilus edulis (Bivalvia: Mollusca). Mar Biol 82:233-240

KHawkins AJS, Smith RFM, Bayne BL, Héral M (1996) Novel observations underlying the fast growth of suspensionfeeding shellfish in turbid environments: Mytilus edulis. Mar Ecol Prog Ser 131:179-190

*Hawkins AJS, James MR, Hickman RW, Hatton S, Weatherhead M (1999) Modelling of suspension-feeding and growth in the green-lipped mussel Perna canaliculus exposed to natural and experimental variations of seston 
availability in the Marlborough Sounds, New Zealand. Mar Ecol Prog Ser 191:217-232

Helm MM, Bourne N (2004) Hatchery culture of bivalves: a practical manual. Fish Tech Pap 471. FAO, Rome

Hewitt JE, Pilditch CA (2004) Environmental history and physiological state influence feeding responses of Atrina zelandica to suspended sediment concentrations. J Exp Mar Biol Ecol 306:95-112

Hornstein J, Espinosa EP, Cerrato RM, Lwiza KMM, Allam B (2018) The influence of temperature stress on the physiology of the Atlantic surfclam Spisula solidissima. Comp Biochem Physiol A Mol Integr Physiol 222:66-73

Isaacs KB, Snapp SS, Chung K, Waldman KB (2016) Assessing the value of diverse cropping systems under a new agricultural policy environment in Rwanda. Food Secur 8:491-506

Jørgensen CB, Riisgård HU (1988) Gill pump characteristics of the soft clam Mya arenaria. Mar Biol 99:107-109

Jørgensen CB, Larsen PS, Riisgård HU (1990) Effects of temperature on the mussel pump. Mar Ecol Prog Ser 64: 89-97

Kach D, Ward JE (2008) The role of marine aggregates in the ingestion of picoplankton-size particles by suspensionfeeding molluscs. Mar Biol 153:797-805

Kamermans P (1993) Food limitation in cockles (Cerastoderma edule (L.)): influences of location on tidal flat and of nearby presence of mussel beds. Neth J Sea Res 31: $71-81$

Kamermans P, van der Veer HW, Karczmarski L, Doeglas GW (1992) Competition in deposit- and suspension-feeding bivalves: experiments in controlled outdoor environments. J Exp Mar Biol Ecol 162:113-135

Kang CK, Choy EJ, Hur YB, Myeong JI (2009) Isotopic evidence of particle size-dependent food partitioning in cocultured sea squirt Halocynthia roretzi and Pacific oyster Crassostrea gigas. Aquat Biol 6:289-302

Kennedy VS, Mihursky JA (1971) Upper temperature tolerances of some estuarine bivalves. Chesap Sci 12:193-204

Kittner C, Riisgård HU (2005) Effect of temperature on filtration rate in the mussel Mytilus edulis: no evidence for temperature compensation. Mar Ecol Prog Ser 305: $147-152$

Kramer J (2019) Littleneck clam and American oyster polyculture: economic viability and nursery technique (project ID:FNE18-901). Northeast Sustainable Agriculture Research and Education Program. https:// projects.sare.org/project-reports/fne18-901/ (accessed 17 Sept 2019)

Kreeger DA, Langdon CJ, Newell RIE (1988) Utilization of refractory cellulosic carbon derived from Spartina alterniflora by the ribbed mussel Geukensia demissa. Mar Ecol Prog Ser 42:171-179

Kreeger DA, Gatenby CM, Bergstrom PW (2018) Restoration potential of several native species of bivalve molluscs for water quality improvement in mid-Atlantic watersheds. J Shellfish Res 37:1121-1158

Lacoste É, Raimbault P, Harmelin-Vivien M, GaertnerMazouni N (2016) Trophic relationships between the farmed pearl oyster Pinctada margaritifera and its epibionts revealed by stable isotopes and feeding experiments. Aquacult Environ Interact 8:55-66

Langdon CJ, Newell RIE (1990) Utilization of detritus and bacteria as food sources by two bivalve suspension-feeders, the oyster Crassostrea virginica and the mussel Geukensia demissa. Mar Ecol Prog Ser 58:299-310
Lesser MP, Shumway SE, Cucci T, Smith J (1992) Impact of fouling organisms on mussel rope culture: interspecific competition for food among suspension-feeding invertebrates. J Exp Mar Biol Ecol 165:91-102

Levinton J (1972) Stability and trophic structure in depositfeeding and suspension-feeding communities. Am Nat 106:472-486

K Levinton J, Ward J, Shumway S (2002) Feeding responses of the bivalves Crassostrea gigas and Mytilus trossulus to chemical composition of fresh and aged kelp detritus. Mar Biol 141:367-376

KLiang J, Crowther TW, Picard N, Wiser S and others (2016) Positive biodiversity-productivity relationship predominant in global forests. Science 354:aaf8957

* Loosanoff VL (1958) Some aspects of behavior of oysters at different temperatures. Biol Bull (Woods Hole) 114:57-70

Matthiessen GC (1960) Observations on the ecology of the soft clam Mya arenaria in a salt pond. Limnol Oceanogr 5:291-300

* Medler S, Silverman H (2001) Muscular alteration of gill geometry in vitro: implications for bivalve pumping processes. Biol Bull (Woods Hole) 200:77-86

Merrill AS, Ropes JW (1969) The general distribution of the surf clam and ocean quahog. Proc Natl Shellfish Assoc 59:40-45

* Møhlenberg F, Riisgård HU (1979) Filtration rate using a new indirect technique in thirteen species of suspensionfeeding bivalves. Mar Biol 54:143-147

Munroe D (2016) Habitat effects on early post-settlement growth of intertidal clams Venerupis philippinarum (A. Adams \& Reeve 1850). J Molluscan Stud 82:507-514

\%Munroe DM, Powell EN, Mann R, Klinck JM, Hofmann EE (2013) Underestimation of primary productivity on continental shelves: evidence from maximum size of extant surfclam populations. Fish Oceanogr 22:220-233

* Munroe DM, Narváez DA, Hennen D, Jacobson L and others (2016) Fishing and bottom water temperature as drivers of change in maximum shell length in Atlantic surfclams (Spisula solidissima). Estuar Coast Shelf Sci 170: $112-122$

*Narváez DA, Munroe DM, Hofmann EE, Klinck JM, Powell EN, Mann R, Curchitser E (2015) Long-term dynamics in Atlantic surfclam (Spisula solidissima) populations: the role of bottom water temperature. J Mar Syst 141: 136-148

Navarro JM, Gonzalez CM (1998) Physiological responses of the Chilean scallop Argopecten purpuratus to decreasing salinities. Aquaculture 167:315-327

* Navarro JM, Leiva GE, Martinez G, Aguilera C (2000) Interactive effects of diet and temperature on the scope for growth of the scallop Argopecten purpuratus during reproductive conditioning. J Exp Mar Biol Ecol 247: 67-83

NMFS (National Marine Fisheries Service) (2018) Fisheries of the United States, 2017. US Department of Commerce, NOAA Current Fishery Statistics No 2017. www.fisheries. noaa.gov/resource/document/fisheries-united-states2017-report (accessed 15 Oct 2019)

*Novais A, Dias E, Sousa R (2016) Inter- and intraspecific variation of carbon and nitrogen stable isotope ratios in freshwater bivalves. Hydrobiologia 765:149-158

Pales Espinosa E, Allam B (2013) Food quality and season affect gene expression of the mucosal lectin MeML and particle sorting in the blue mussel Mytilus edulis. Mar Biol 160:1441-1450 
Pales Espinosa E, Allam B (2018) Reverse genetics demonstrate the role of mucosal C-type lectins in food particle selection in the oyster Crassostrea virginica. J Exp Biol 221:jeb174094

Pales Espinosa E, Perrigault M, Ward JE, Shumway SE, Allam B (2010a) Microalgal cell surface carbohydrates as recognition sites for particle sorting in suspension-feeding bivalves. Biol Bull (Woods Hole) 218:75-86

* Pales Espinosa E, Hassan D, Ward JE, Shumway SE, Allam B (2010b) Role of epicellular molecules in the selection of particles by the blue mussel Mytilus edulis. Biol Bull (Woods Hole) 219:50-60

Pales Espinosa E, Cerrato RM, Wikfors G, Allam B (2016a) Modeling food choice in the two suspension-feeding bivalves Crassostrea virginica and Mytilus edulis. Mar Biol 163:2-13

Pales Espinosa E, Koller A, Allam B (2016b) Proteomic characterization of mucosal secretions in the eastern oyster Crassostrea virginica. J Proteomics 132:63-76

* Peterson CH (1982) The importance of predation and intraand interspecific competition in the population biology of two infaunal suspension-feeding bivalves Protothaca staminea and Chione undatella. Ecol Monogr 52: $437-475$

Peterson CH (1992) Competition for food and its communitylevel implications. Benthos Res 42:1-11

* Peterson CH, Andre SV (1980) An experimental analysis of interspecific competition among marine filter feeders in a soft-sediment environment. Ecology 61:129-139

Prins T, Escaravage V (2005) Can bivalve suspensionfeeders affect pelagic food web structure? In: Dame RF, Olenin S (eds) The comparative roles of suspension-feeders in ecosystems. NATO Science Series IV. Earth and Environmental Sciences-Vol 47. Springer, Dordrecht, p 31-52

Pyke GH (1982) Local geographic distributions of bumblebees near Crested Butte, Colorado: competition and community structure. Ecology 63:555-573

Riera P, Stal LJ, Nieuwenhuize J (2002) $\delta^{13} \mathrm{C}$ versus $\delta^{15} \mathrm{~N}$ of co-occurring molluscs within a community dominated by Crassostrea gigas and Crepidula fornicata (Oosterschelde, The Netherlands). Mar Ecol Prog Ser 240: 291-295

Riisgård HU (1988) Efficiency of particle retention and filtration rate in 6 species of Northeast American bivalves. Mar Ecol Prog Ser 45:217-223

* Riisgård HU (2001) On measurement of filtration rates in bivalves - the stony road to reliable data: review and interpretation. Mar Ecol Prog Ser 211:275-291

* Riisgård HU, Seerup DF (2003) Filtration rates in the soft clam Mya arenaria: effects of temperature and body size. Sarsia 88:416-428

Riisgård HU, Kittner C, Seerup DF (2003) Regulation of opening state and filtration in filter-feeding bivalves (Cardium edule, Mytilus edulis, Mya arenaria) in response to low algal concentration. J Exp Mar Biol Ecol 284:105-127

Robbins HM, Bricelj VM, Ward JE (2010) In vivo effects of brown tide on the feeding function of the gill of the northern quahog Mercenaria mercenaria (Bivalvia: Veneridae). Biol Bull (Woods Hole) 219:61-71

Robinson WE, Wehling WE, Morse MP (1984) The effect of suspended clay on feeding and digestive efficiency of the surf clam Spisula solidissima (Dillwyn). J Exp Mar Biol Ecol 74:1-12
Rosa M, Ward JE, Shumway SE, Wikfors GH, Pales Espinosa E, Allam B (2013) Effects of particle surface properties on feeding selectivity in the eastern oyster Crassostrea virginica and the blue mussel Mytilus edulis. J Exp Mar Biol Ecol 446:320-327

Rosa M, Ward JE, Holohan BA, Shumway SE, Wikfors GH (2017) Physicochemical surface properties of microalgae and their combined effects on particle selection by suspension-feeding bivalve molluscs. J Exp Mar Biol Ecol 486:59-68

Rosa M, Ward JE, Shumway SE (2018) Selective capture and ingestion of particles by suspension-feeding bivalve molluscs: a review. J Shellfish Res 37:727-746

Rosenfeld JS (2002) Functional redundancy in ecology and conservation. Oikos 98:156-162

Russell EP (1989) Enemies hypothesis: a review of the effect of vegetational diversity on predatory insects and parasitoids. Environ Entomol 18:590-599

Schoener TW (1974) Resource partitioning in ecological communities. Science 185:27-39

Shumway SE, Selvin R, Schick DF (1987) Food resources related to habitat in the scallop Placopecten magellanicus (Gmelin 1791): a qualitative study. J Shellfish Res 6: 89-95

Snelgrove PV, Grassle JP, Butman CA (1998) Sediment choice by settling larvae of the bivalve Spisula solidissima (Dillwyn) in flow and still water. J Exp Mar Biol Ecol 231:171-190

Solow AR, Gallager SM (1990) Analysis of capture efficiency in suspension feeding: application of nonparametric binary regression. Mar Biol 107:341-344

* Spooner DE, Vaughn CC (2009) Species richness and temperature influence mussel biomass: a partitioning approach applied to natural communities. Ecology 90: 781-790

* Stecher HA III, Krantz DE, Lord CJ III, Luther GW III, Bock KW (1996) Profiles of strontium and barium in Mercenaria mercenaria and Spisula solidissima shells. Geochim Cosmochim Acta 60:3445-3456

* Steiner CF, Long ZT, Krumins JA, Morin PJ (2005) Temporal stability of aquatic food webs: partitioning the effects of species diversity, species composition and enrichment. Ecol Lett 8:819-828

Steiner CF, Long ZT, Krumins JA, Morin PJ (2006) Population and community resilience in multitrophic communities. Ecology 87:996-1007

Suedel BC, Clarke JU, Wilkens J, Lutz CH, Clarke DG (2015) The effects of a simulated suspended sediment plume on eastern oyster (Crassostrea virginica) survival, growth, and condition. Estuaries Coasts 38:578-589

* Tilman D, Reich PB, Knops JH, Wedin D, Mielke T, Lehman C (2001) Diversity and productivity in a long-term grassland experiment. Science 294:843-845

* Tilman D, Reich PB, Knops JM (2006) Biodiversity and ecosystem stability in a decade-long grassland experiment. Nature 441:629-632

USDA (2014) The 2012 Census of Agriculture: Census of Aquaculture (2013), Vol 3, Special Studies, Part 2. United States Department of Agriculture, National Agricultural Statistics. www.nass.usda.gov/Publications/AgCensus/ 2012/Online_Resources/Aquaculture/ (accessed 15 Oct 2016)

*Valentine MM, Butler MJ IV (2019) Sponges structure water-column characteristics in shallow tropical coastal ecosystems. Mar Ecol Prog Ser 608:133-147 
Velasco LA, Navarro JM (2005) Feeding physiology of two bivalves under laboratory and field conditions in response to variable food concentrations. Mar Ecol Prog Ser 291: 115-124

Ward JE, Newell RIE, Thompson RJ, MacDonald BA (1994) In vivo studies of suspension-feeding processes in the eastern oyster Crassostrea virginica (Gmelin). Biol Bull (Woods Hole) 186:221-240

Ward JE, Levinton JS, Shumway SE, Cucci T (1997) Site of particle selection in a bivalve mollusk. Nature 390:131-132

Editorial responsibility: Jean-Sébastien Lauzon-Guay, Dartmouth, Nova Scotia, Canada
Whalen MA, Stachowicz JJ (2017) Suspension feeder diversity enhances community filtration rates in different flow environments. Mar Ecol Prog Ser 570:1-13

* Wright RT, Coffin RB, Ersing CP, Pearson D (1982) Field and laboratory measurements of bivalve filtration of natural marine bacterioplankton. Limnol Oceanogr 27:91-98

* Yahel G, Marie D, Beninger PG, Eckstein S, Genin A (2009) In situ evidence for pre-capture qualitative selection in the tropical bivalve Lithophaga simplex. Aquat Biol 6: 235-24

Submitted: October 17, 2019; Accepted: February 17, 2020 Proofs received from author(s): March 21, 2020 